УДК 81

DOI $10.25205 / 2410-7883-2020-1-260-290$

\title{
Художники Заболоцкого
}

\author{
А. Б. Устинов ${ }^{1}$, И. Е. Лощилов ${ }^{2,3}$ \\ ${ }^{1}$ Книгоиздательство «Аквилон» \\ Сан-Франциско, США \\ ${ }^{2}$ Институт филологии СО РАН \\ Новосибирск, Россия \\ ${ }^{3}$ Новосибирский государственный педагогический университет \\ Новосибирск, Россия
}

\section{Аннотачия}

Настоящая работа посвящена истории творческих и биографических связей Николая Заболоцкого с художниками начиная с его дебютной книги стихотворений «Столбцы», вышедшей в свет в феврале 1929 г.

Заболоцкий может считаться художником как в широком (художник как творец), так и в конкретно-профессиональном смысле: еще до «Столбцов» он посещал мастерскую Павла Филонова, рисовал и даже оформлял самодельные рукописные книги, придерживаясь техники «аналитического искусства». Сохранилось несколько каллиграфически переписанных им стихотворений, в том числе включенных в его рукописный сборник «Арарат» (1928). Композиционным центром нарисованной самим Заболоцким обложки к сборнику выступает изображение распластанной шкурки, встречающееся на страницах оформленной Верой Ермолаевой (1893-1937) детской книжки «Хорошие сапоги» (1928).

Когда в том же 1928 г. был поднят вопрос о подготовке поэтической книги для «Издательства писателей в Ленинграде», Заболоцкий обратился с просьбой о ее оформлении к художнику Льву Юдину (1903-1941), сотрудничавшему с Казимиром Малевичем в Гинхуке. Однако издательство предпочло выпустить «Столбцы» в типовой обложке. Юдин работал также над оформлением несостоявшегося издания книги Заболоцкого «Цирк» и над иллюстрациями к его невышедшему рассказу об индейцах, частично напечатанными в журнале «Ёж».

Сохранился эскиз обложки «Столбцов» работы Ермолаевой, которая вместе с Юдиным исполнила афишу знаменитого вечера обэриутов «Три левых часа», состоявшегося 24 января 1928 г. в ленинградском Доме печати. Замечательная обложка Ермолаевой рассматривается здесь в контексте основных мотивов стихотворений Заболоцкого, включенных им в его первую книгу.

Творческий союз поэта и близких ему художников реализовался в их работе на поприще детской литературы, в первую очередь в знаменитых журналах для детей «Ёж» и «Чиж», издававшихся под редакцией Самуила Маршака. Особый интерес представляет публикация «Сказки о кривом человечке» (1933), оформленная Павлом Кондратьевым (1902-1985), который, как и Заболоцкий, посещал мастерскую Филонова. На одной из иллюстраций художник изобразил поэта вместе с его сыном Никитой.

Ключевые слова

журналы «Ёж» и «Чиж», Николай Заболоцкий, искусство книги, иллюстрация, детская литература 1920-х годов, Лев Юдин, Вера Ермолаева, Павел Кондратьев

(C) А. Б. Устинов, И. Е. Лощилов, 2020

ISSN 2410-7883

Сюжетология и сюжетография. 2020. № 1

Studies in Theory of Literary Plot and Narratology, 2020, no. 1 
Для циттирования

Устинов А. Б., Лощъилов И. Е. Художники Заболоцкого // Сюжетология и сюжетография. 2020. № 1. С. 260-290. DOI 10.25205/2410-7883-2020-1-260-290

\title{
Nikolai Zabolotsky and His Artists
}

\author{
A. B. Ustinov ${ }^{1}$, I. E. Loshchilov ${ }^{2,3}$ \\ 1 “Aquilon” Books \& Publishing \\ San Francisco, USA \\ ${ }^{2}$ Institute of Philology SB RAS \\ Novosibirsk, Russian Federation \\ ${ }^{3}$ Novosibirsk State Pedagogical University \\ Novosibirsk, Russian Federation
}

Abstract

The essay reconstructs the history of Nikolai Zabolotsky's relations with artists, starting with his debut book of poems "The Pillars," published in February 1929 and throughout the 1930s. Zabolotsky can be considered an artist both in a broad (an artist as a creator) and in a professional sense: before "The Pillars," he attended Pavel Filonov's workshop, created some drawings, and designed his handwritten books using the technique of Filonov's "analytical art." He included some of these calligraphic manuscripts in his collection "Ararat" (1928). He also painted the cover putting in the center of the composition an image of a spread skin, borrowed from Vera Ermolaeva's illustrations for his children's book "Good Boots" (1928).

The same year Zabolotsky was asked to prepare a collection of his poems for the "Publishing House of Writers in Leningrad." He asked another artist Lev Yudin (1903-1941), who collaborated with Kazimir Malevich in Ginkhuk, to make a cover for "The Pillars." However, the publishing house went with a different design, and Yudin's cover was lost. He also worked on the design of Zabolotsky's book "The Circus," which he envisioned as a livre d'artiste, as well as on illustrations for a never published story "The Indians" (1929).

Vera Ermolaeva (1893-1937) made her own cover for "The Pillars" a study of which is preserved in the Russian Museum. She also collaborated with Yudin on drawing a poster for the famous OBERIU performance "Three Left Hours," held on January 24, 1928, at the Leningrad Press House. Her remarkable cover for "The Pillars" is discussed here in connection with the poems, selected by Zabolotsky for his first book.

His creative collaboration with the artists found its realization in the field of children's literature, primarily in the famous magazines "Hedgehog" and "Siskin," published under the editorial supervision of Samuil Marshak. The publication of Zabolotsky's "The Tale of the Crooked Man" (1933) in "Siskin" magazine is of particular interest. The poem was illuminated by Pavel Kondratiev (1902-1985), who also attended Filonov's workshop, and depicted the poet together with his son Nikita in one of his illustrations.

Keywords

magazines "Iozh" and "Chizh", Nikolai Zabolotsky, "Stolbtsy", OBERIU, illustration, children's literature of the 1920s and the 1930s, Lev Yudin, Vera Ermolaeva, Pavel Kondratiev, Samuil Marshak

For citation

Ustinov A. B., Loshchilov I. E. Nikolai Zabolotsky and His Artists. Studies in Theory of Literary Plot and Narratology, 2020, no. 1, p. 260-290. (in Russ.) DOI 10.25205/2410-78832020-1-260-290 
Вы смотрите у меня: Юдин, Эндер, Ермолаева Грызите подрамники вежливо, от первого до 318-ого. Они вас незатейливых всему научат.

Игорь Бахтерев

Вот что нарисуем мы на наших картинах.

Тот, кто увидит их раз - не забудет до гроба.

Николай Заболоикий

Книга стихотворений Николая Заболоцкого «Столбцы» вышла в свет в феврале 1929 г. Об издании сборника было объявлено 20 января: «Ленинградское издательство писателей на днях выпускает из печати: <..> Н. Заболоцкий, стихи “Столбцы”» [Без подписи, 1929a, с. 29], а уже месяц спустя Заболоцкий надписывал первые экземпляры филологу Борису Эйхенбауму, переводчику Давиду Выгодскому ${ }^{1}$ и художнику Константину Рождественскому ${ }^{2}$. Неделю спустя Заболоцкий надписал «Столбцы» Игорю Бахтереву, своему соратнику по Объединению Реального Искусства: «Игорю - Николай. 28/II-1929 г.» ${ }^{3}$.

Это был уникальный и мало с чем сравнимый литературный дебют. Начинающий поэт и журналист Исаак Синельников (1905-1986) через сорок с лишним лет вспоминал разговор с Заболоцким накануне выхода книги в свет:

Николай Алексеевич затопил печку. Мы сидели с ним на корточках и смотрели на огонь. Я сказал:

- Ну вот, через несколько дней выйдет ваша книга. Может быть, как Байрон, вы однажды проснетесь знаменитым.

Он улыбнулся и сказал, что сейчас другие времена и все обстоит значительно сложнее, чем при Байроне.

Но я напророчил: он действительно проснулся знаменитым [Воспоминания..., 1984, c. 119].

«Столбцы» представляли поэта, печатные выступления которого до выхода книги были эпизодическими [Заболоцкий, 1928а, с. 4; 1928б, с. 6; 1928в, с. 8; 1928 г, с. $3 ; 1928$ д, с. 3], но и их Заболоцкий оставил в основном «за кадром», включив в сборник только «Красную Баварию» и «Футбол» [Заболоцкий, 1927а;

\footnotetext{
1 «Борису Михайловичу Эйхенбауму - Н. Заболоцкий. 19.ІІ.1929»; «Д. И. Выгодскому Н. Заболоцкий. 19.II.1929» [Книги и рукописи..., 1989, с. 98].

2 «Константину Ивановичу Рождественскому - в знак единения искусств! Ваш Н. Заболоцкий 19.ІІ.1929». В дневнике адресата этот дар был отмечен в записи 20 февраля: «Получил от Заболоцкого книгу. Рад» [Константин Рождественский..., 2006, с. 304]. Подаренный Рождественскому экземпляр «Столбцов» хранится у наследников художника.

${ }^{3}$ Нынешнее местонахождение этого экземпляра «Столбцов» неизвестно. Другие найденные инскрипты: «Лидии Константиновне Степановой / целует ручки / Н. Заболоцкий / 20.II.29» (Библиотека РГАЛИ); «П. Н. Лукницкому Н. Заболоцкий. 24/X-1929 г.» [Двинятина, 2006, с. 579]. Известно также о надписи на сборнике отцу, Алексею Агафоновичу За́болотскому: «Дорогому папе - благодарный сын. / Н. Заболоцкий. / 12 авг. 1929 г.» [Заболоцкий, 2018, с. 134].
} 
1927б]. Именно они, тем не менее, определили поэтическую динамику его «Столбцов». Вряд ли какая-либо другая первая книга позволяла создать представление о поэте, его литературной силе и художественной изысканности. С появлением «Столбцов» Заболоцкий немедленно занял ведущее положение в литературной культуре своей эпохи, что признал, например, Юрий Тынянов, надписавший ему свою книгу «Архаисты и новаторы», также вышедшую в 1929 г.: «Первому поэту наших дней» [Заболоцкий, 2018, с. 97] ${ }^{4}$.

Единственным слабым местом «Столбцов» оказалось навязанное издательством оформление сборника. Как вспоминал И. Синельников, «Николай Алексеевич был огорчен тем, что издательство утвердило бесцветную и трафаретную обложку книги работы художника Кирнарского, тогда как художник Юдин сделал яркую, красочную обложку, вполне отвечающую духу книги» [Воспоминания..., 1984, с. 119]. У Марка Кирнарского (1893-1941) прежде случались оформительские удачи - как, например, барочная обложка для сборника стихотворений Николая Бернера «Осень мира» (Киев, 1922), но к 1929 г. он стал штатным художником «Издательства писателей в Ленинграде» и сделал «Столбцы» «под кальку» с макета поэмы Вольфа Эрлиха «Софья Перовская» (Л., 1929).
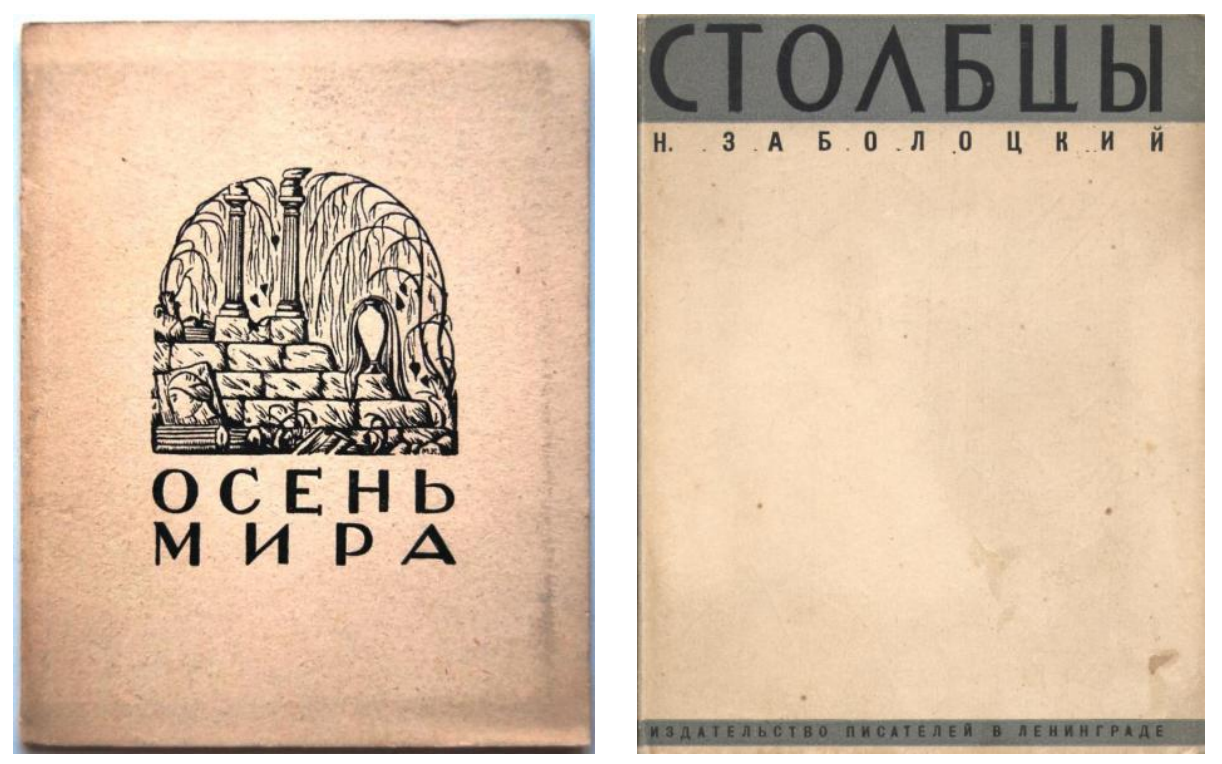

Марк Кирнарский. Обложки к книгам Николая Бернера «Осень мира» (1922) и Николая Заболоцкого «Столбцы» (1929)

Mark Kirnarsky. Covers for Nikolai Berner's "Autumn of the World” (1922) and Nikolai Zabolotsky's “The Pillars" (1929)

\footnotetext{
${ }^{4}$ Поэт Виктор Кривулин вспоминал, как «...в $<19>60$-м году за рубль, то есть за 10 пореформенных копеек, купил “Столбцы” Заболоцкого с автографом Тынянову», но книга у него не сохранилась [Кулаков, 1999, с. 362].
} 
Заболоцкий же представлял себе совсем иную обложку, поэтому еще до сдачи рукописи в издательство обратился к художнику Льву Юдину (1903-1941), ученику Казимира Малевича, с предложением выполнить оформление «Столбцов» в стилистике, близкой к плакату знаменитого вечера «Три левых часа», который состоялся 24 января 1928 г. в ленинградском Доме печати. Подготовка книги велась как раз в период утверждения ОБЭРИУ, одним из направлений деятельности которого было определено активное сотрудничество с художниками. «В 1926-1927 гг. группа стремится к расширению, - отмечал Вл. Эрль: - в это время рассматриваются кандидатуры будущих членов группы, <..> ведутся, в частности, переговоры о слиянии с Уновисом К. С. Малевича, - при этом даётся обещание дать 20 человек "III разряда" (Д. Хармс, зап. кн. № 8)» [Вокруг Хармса, 1984 , c. $<100-101>$ ].

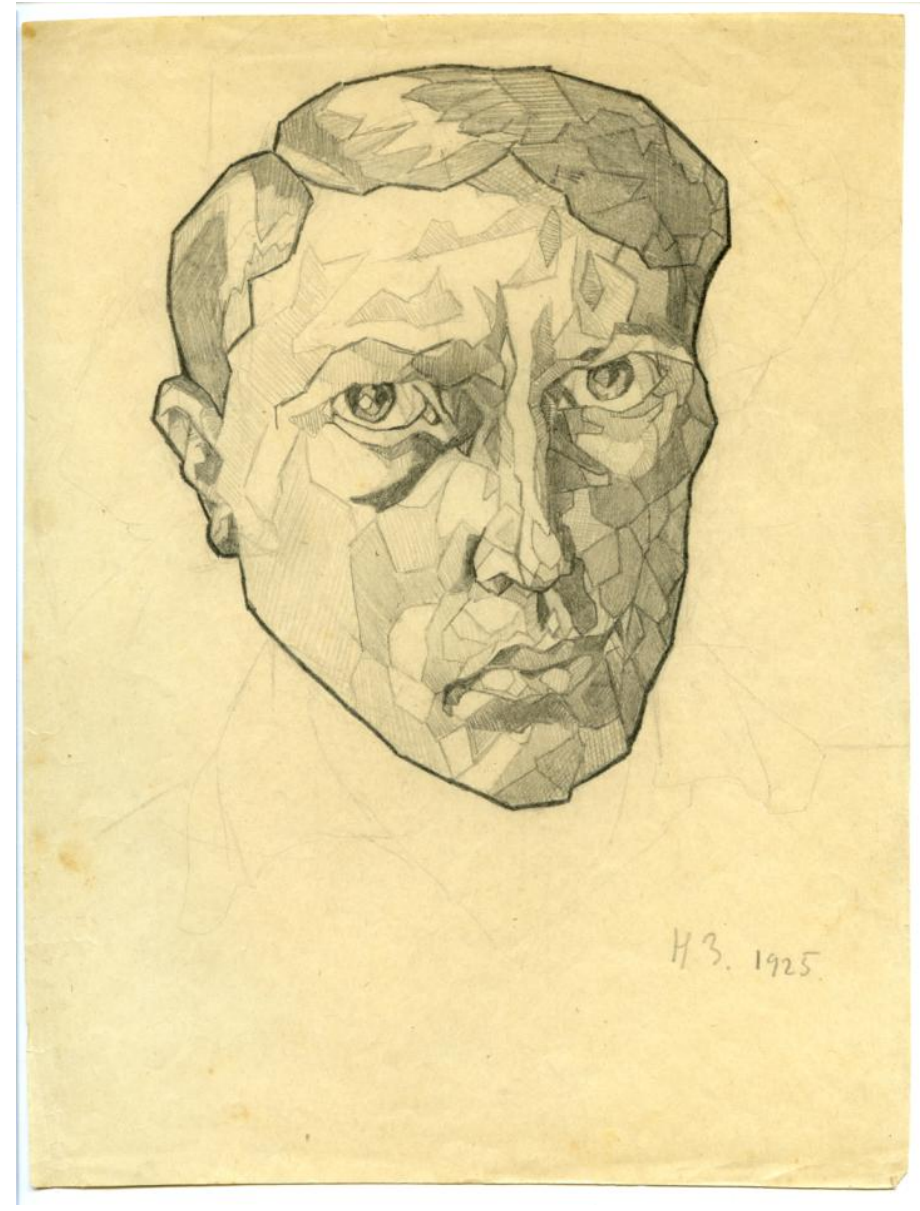

Николай Заболоцкий. Автопортрет, 1925

Nikolai Zabolotsky. Self-Portrait (1925)

ISSN 2410-7883

Сюжетология и сюжетография. 2020. №

Studies in Theory of Literary Plot and Narratology, 2020, no. 
Более того, в «I сборнике "Радикс"», проект которого составлялся весной 1927 г., Заболоцкий в том числе предполагал выступить и как художник наравне с Павлом Филоновым, у которого брал уроки рисунка. Его стихотворение 1926 г., написанное в стилистике «левого искусства» помечено «после посещения худ<ожника> Филонова»:

я голого не пью и не люблю

и эту тоже не люблю а знаю

сейчас я ей открою белый рот

и перепонку заведу над жаброй

теперь душа не спи пошто вокруг стола

дымок мой развиваться начинает

а тут во рту в тринадцать молоточков

мир ежедневный запевает ${ }^{5}$.

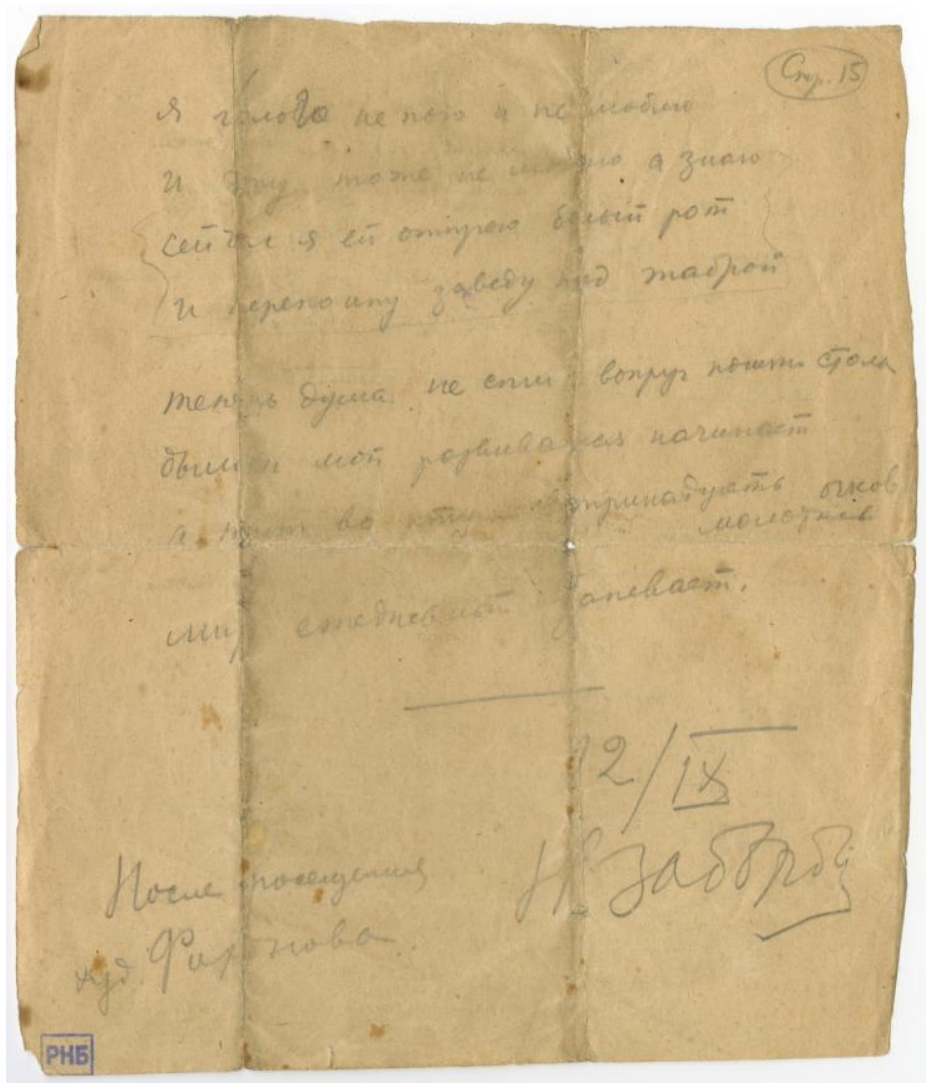

Николай Заболоцкий. Автограф стихотворения «я голого не пью и не люблю...»

Nikolai Zabolotsky. An autograph of his 1926 poem

\footnotetext{
${ }^{5}$ Впервые опубликовано [Вокруг Хармса, 1984, с. <102>].
} 

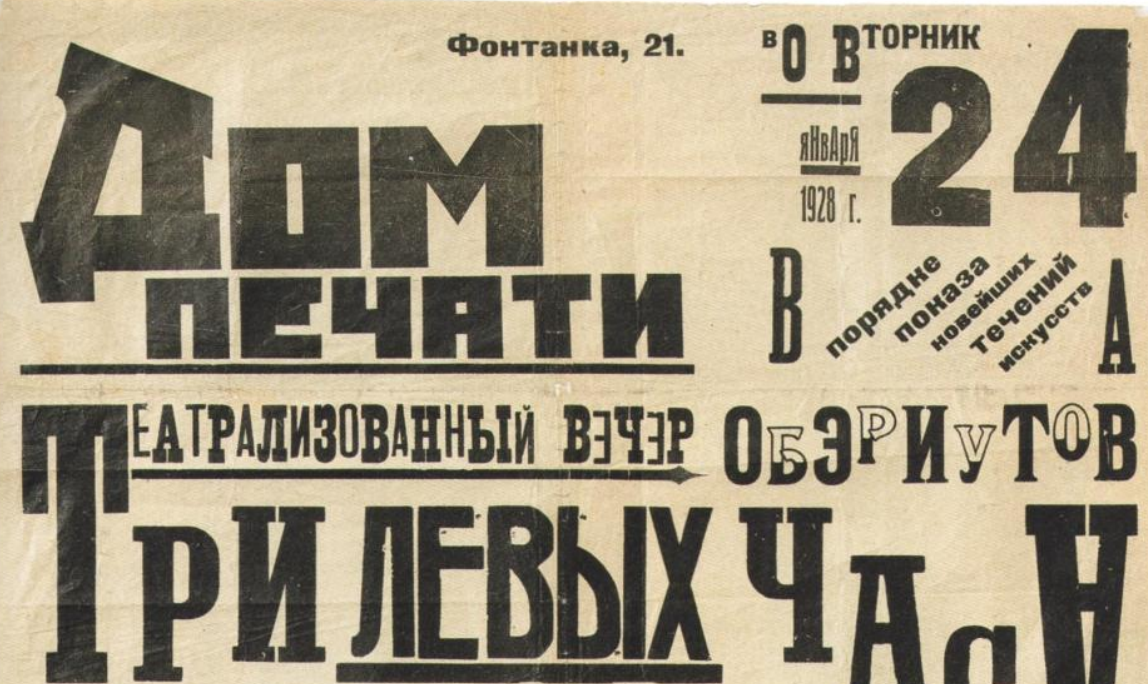

оБэриу-0б'единение Реального искусства. ЛИтература-ИЗО-КИНО-ТЕАТР.

Первый час. Вступление. Декларация Обзрну. Декларация Литературной Секции.
पитают
К. К. Вагинов
Н. Забопоцкий
Даниил Хармс
Игорь Бахтерев
А. Введенский

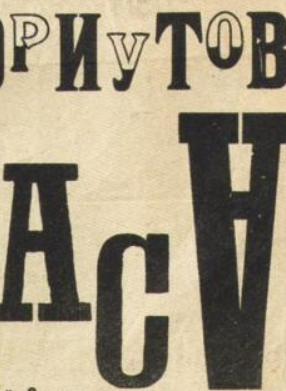

Второй час.

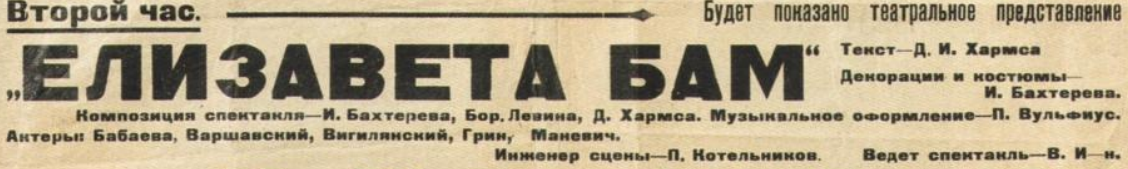

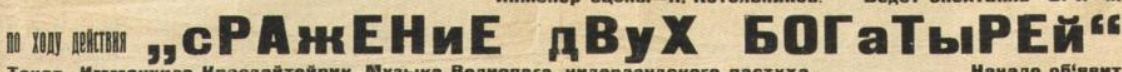

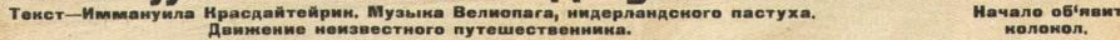
Третий час. $\longrightarrow$ Вечернев размышление о путях кино-Александр Разумовский.

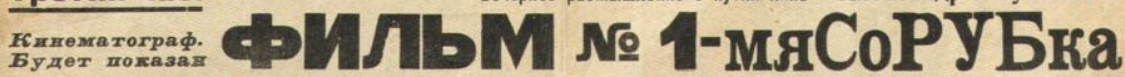

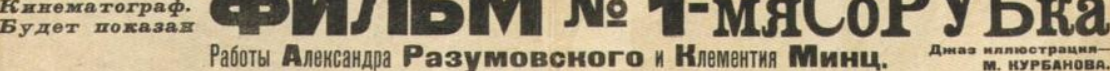

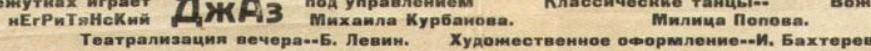
1 1 C I Начапо в $7 \frac{1}{2}$ час. веч. Цены местам от 40 коп. до 2 руб. Члекам А. п. екиама 50'

Готоветея $\mathrm{k}$ постановkе

Афиша для вечера ОБЭРИУ «Три левых часа». Январь 1928 г.

Poster for the OBERIU performance "Three Left Hours" (1928) 
28 июня 1928 г. Заболоцкий писал Юдину:

Дорогой Лев Александрович,

наступило время написать Вам деловое письмо, содержание которого Вы, вероятно, знаете со слов Стерлигова. Дело в том, что К<нигоиздательст>во писателей берет в печать мою книгу стихов, которую предполагает выпустить осенью в сентябре-октябре этого года. Я уже давно хотел обратиться к Вам с просьбой сделать для этой книжки обложку. $<\ldots>$

В этом деле нельзя рассчитывать на материальное вознаграждение, т. к. К<нигоиздательст>во существует тоже в кредит и, напр <имер>, я за книгу ничего не получаю. Если Вы и не отказались бы сделать эту работу, то лишь как дружескую услугу для меня лично. Мне кажется, что Ваш шрифт, использованный для большого плаката к «3 обэриутским часам» очень идет к книге. Обложка очень простая, шрифтовая. <..>

Слово «Столбцы» должно быть сделано Вашим шрифтом, оно доминирует. Шрифт своеобразный, но строгий и законченный. В нем - вся соль. С виду будто бы ничего особенного, а приглядишься - и открывается совершенно новое дело. Два цвета: белый и черный. Размер точно пока сказать не могу. Вероятно $13,5 \times 20,5$ сант $>$ иметров $>$. Вроде последней книги Пастернака ${ }^{6}$ [Заболоцкий, 1984, с. $306-$ 307].

Получив положительный ответ, Заболоцкий повторно писал художнику 9 августа: «Книга должна выйти в свет - в сентябре-октябре, т. е. в конце августа она пойдет в набор. К этому времени надо готовить обложку. <... Дело "на мази”; нужно, чтобы книга вышла к началу сезона. Это очень важно. <..> Обложку построже, но с изюминкой - сами знаете» [Там же, с. 308]. Под «изюминкой» подразумевался тот самый плакат, над которым Юдин работал вместе с коллегой по Гинхуку Верой Ермолаевой (1893-1937).

Их сотрудничество не было случайным: оба художника вышли из школы Казимира Малевича, который считал их своими преданными последователями. Восстанавливая после перерыва эпистолярное общение с Лазарем Лисицким, Малевич в письме 17 июня 1924 г. назвал Ермолаеву и Юдина «самыми главными борцами» в сражениях за учреждение Гинхука:

Года полтора жизни в Ленинграде <прошли> при весьма сильной оппозиции против Нового Искусства и голодовке $<\ldots .>$.

Но, несмотря на все поставленные авангарды реакционеров, захвативших Академию и Штиглица и Музей Худ<ожественной> Культуры, я все же повел атаки против их позиций по примеру Витебска; надо сказать, что со мной приехали и Юдин, и $\mathrm{B}<$ ера $>\mathrm{M}<$ ихайловна $>$. Это самые главные борцы, которые великолепно повели работу снизу, я же сверху; в результате получилось разгром гоп-компании, засевшей в Муз<ее> Худ<ожественной> Культуры во главе с идиотом Татлиным, который, будучи зав. Изо <заведующим Отделом изобразительных искусств. А. У., И. Л.>, сдал все позиции правым <..>. Сейчас же при сильнейшей реакции, развивающейся у нас против Нов $<$ ого $>$ Искус $<$ ства $>$, всё же удалось овладеть последней позицией Нов $<$ ого $>$ Ис $<$ кусства $>$ - это Муз $<$ ей $>$ Худ<ожественной $>$ Кул<ьтуры $>$ - которую держали претенденты на Новое. В настоящее время Муз<еем> Худ<ожественной> Кул<ьтуры> овладели и удалось построить исследо-

\footnotetext{
${ }^{6}$ Издательский размер «Столбцов» $(18 \times 13,3$ см) оказался меньше, чем у сборника
} «Две книги. Стихи» (М.; Л., 1927) Бориса Пастернака (20 × 13,5 см). 
вательский Институт, которого нет во всем мире; долго ли придется жить, неизвестно [Малевич, 2003, с. 296-297] ${ }^{7}$.

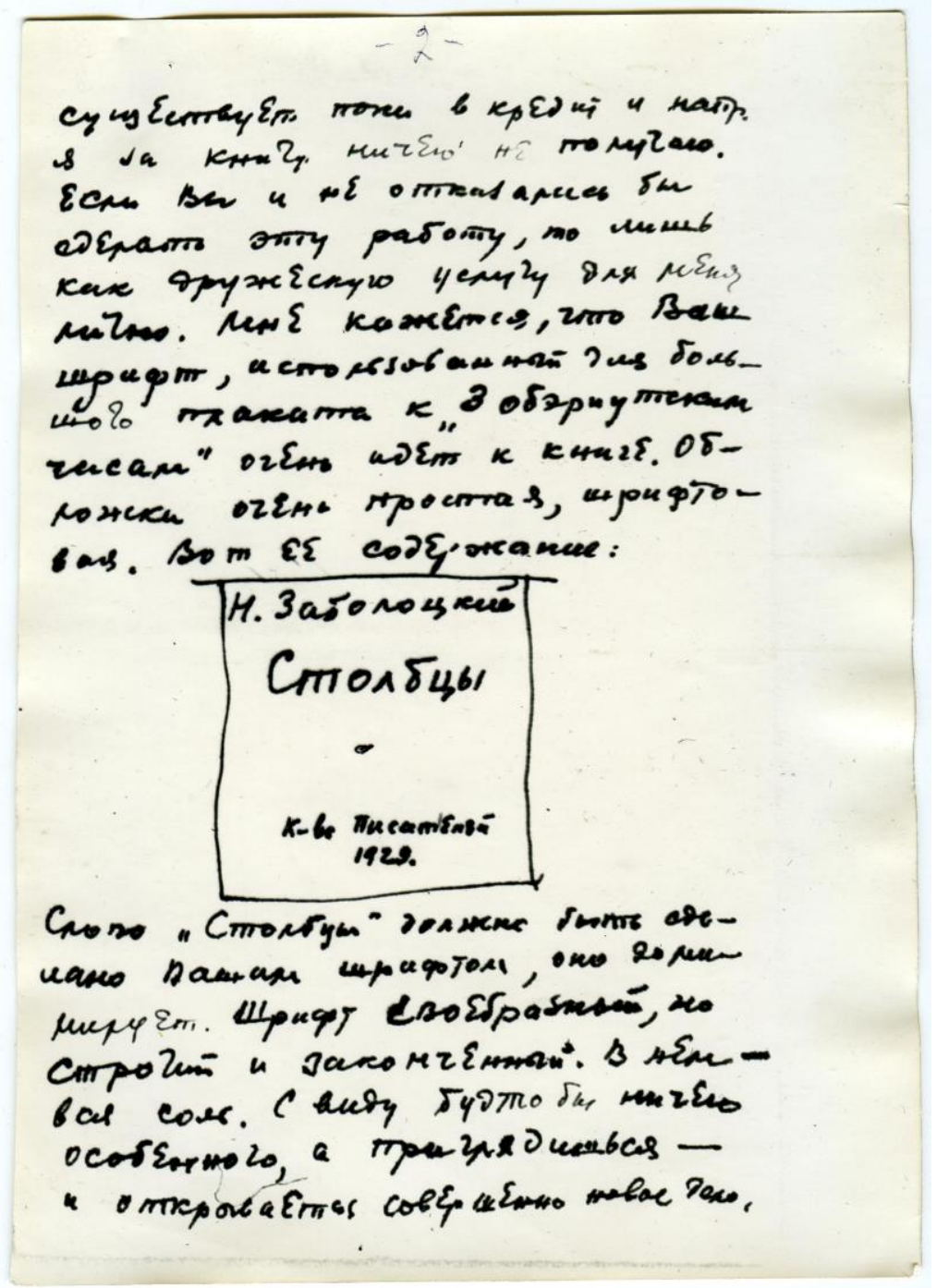

Автограф письма Н. Заболоцкого к Л. Юдину от 28 июня 1928 г.

Nikolai Zabolotsky's letter to Lev Yudin (June 28, 1928)

${ }^{7}$ В ответном письме 1 июля 1924 г. Лисицкий поздравлял Малевича с обретением Гинхука: «Я рад за Вас, что Вы теперь имеете в своих руках Институт. <...> Желаю Вам от всей души, чтоб учреждение Ваше (а на свете такого нет) было бы живым заводом, а не превратилось бы в закостеневшее Мандаринство. Очень большая и благодарная работа перед Вами» [Малевич, 2003, с. 300].

ISSN 2410-7883

Сюжетология и сюжетография. 2020. №

Studies in Theory of Literary Plot and Narratology, 2020, no. 1 
Впрочем, к зиме 1928 г. оба художника уже отошли от ригорической методики Малевича. 4 марта Ермолаева писала своему другу и конфиденту Борису Эндеру: «Мое положение чрезвычайно трудное, так как в отношении работы я отошла от группы $\mathrm{M<алеви>ча} \mathrm{-} \mathrm{они} \mathrm{выставляют} \mathrm{осенью} \mathrm{-} \mathrm{и} \mathrm{пока} \mathrm{работаю} \mathrm{только} \mathrm{с} \mathrm{Юди-}$ ным без какой-либо поддержки откуда бы то ни было, с общим отрицанием» [Ермолаева, 1999, с. 175].

В дневнике Юдин описывал все стадии подготовки афиши, которая увлекла его так, что он даже отказался от лыжной прогулки с сестрой в Сосновке:

В это воскресенье <т. е. 22 января 1928 г. - А. У., И. Л.> не поехал из-за плаката Обэриу.

Вот это событие! Впервые моя форма, моя собственная форма, которая была дана не по обязанности, а с любовью - вошла в жизнь и оказалась на высоте.

Очень приятно.

Приятно то, что сделали вещь просто, без мук и выдумывания. Опустили руку в карман, вытащили монетку и заплатили.

Белый снег [Юдин, 2017, с. 184].

«Белый снег» - название livre d'artiste Юдина, которая погибла во время блокады. Его близкий друг Константин Рождественский обратил внимание в письме к М. Гороховой 9 августа 1962 г., что одна из страниц «Белого снега» стала фоном для обэриутской афиши: «У него есть книжка - называется, кажется, “Белый снег”. Она не издана. Это станковая книжка. Это серия гуашей размером книж<ным>. Там есть листы “Белый снег” или ритм букв на черном фоне - белые буквы даны, кажется, наклонно. Лев увеличил эту страницу до метров 4 и на фоне наклеил афишу - о спектакле, кажется, Терентьева» [Там же, с. 798-799] ${ }^{8}$.

Далее Юдин раскрывал подробности, как «просто и радостно» вместе с Ермолаевой они готовили «плакат Обэриу»:

Вчера показывал Бахтереву.

Аx, шпана маленькая... <...>

Приятно работать с $\mathrm{B}<$ ерой $>\mathrm{M}<$ ихайловной $>$ (это по поводу плаката). Она отличный работник. Быстро, спокойно, без шума и драм. Полная противоположность мне.

Мы с ней хорошо сработались и понимаем друг друга с полуслова. Она часто бывает скромна и тактична. <...>

Завтра вечер Обэриу.

Жду с нетерпением - пойду с удовольствием - уйду?..

В Заболоцкого я влюбляюсь. Приятный малый. Он надежнее всех их. <..>

P. S. Сегодня специально по морозу и ветру бегал смотреть, как выглядит наш плакат.

Оказывается, эти черти <т. е. обэриуты. - А. У., И. Л.> еще не выспались его поставить.

Отзыв Терентьева:

- «Культурно и нагло.

То, что надо».

8 За давностью лет Рождественский перепутал вечер «Три левых часа» с одной из постановок Игоря Терентьева на той же сцене ленинградского Дома печати. 
В точку.

Но это со стороны зрителя. А делалось так же просто и радостно, как и всё [Юдин, 2017, с. 184-186].

Участник и один из организаторов вечера «Три левых часа» Игорь Бахтерев рассказывал, как происходила уличная инсталляция «сделанного по просьбе Заболоцкого» плаката к вечеру «Три левых часа»:

Информационный журнал Дома печати с нашими статьями день в день появился в продаже, афиши расклеены, и впечатляющий плакат, сделанный по просьбе Заболоцкого художниками Гинхука Ермолаевой и Юдиным, уже установлен на Аничкином мосту и постоянно собирает любопытных.

$<. .>$ Вместе с типографщиками мы, к их удивлению, выбирали вышедшие из употребления, однако красивые шрифты, вместе размещали текст, даже вмешивались в дела расклейщиков: по предложению Николая <Заболоцкого> помещали по две афиши рядом - одна как полагается, другая - перевернутая.

- Чтобы прохожие внимание обращали и задерживались, - объяснил он, - и не ошибся.

Теперь несколько слов про плакат, стоявший, как вы уже знаете, на углу Невского и набережной Фонтанки. Причина всеобщего внимания к нему объяснялась не изыском шрифта, а блестящей композиционной находкой. Плакат выглядел небольшой вырезкой из огромного, вернее сказать, исполинского плаката. Естественно, что на такую «вырезку» могли попасть только отдельные буквы-великаны, только отрывки многометровых слов. Они-то и служили фоном для наших печатных афиш, казавшихся крохотными листочками [Воспоминания..., 1984, с. 93].

Отвечая на просьбу Заболоцкого об обложке для «Столбцов», Юдин позаимствовал в качестве основного шрифта те самые «отдельные буквы-великаны» из плаката к «3 обэриутским часам» ${ }^{9}$, как об этом вспоминал Рождественский:

Обложка для сборника «Столбцы» была сделана Юдиным. Издательству она не понравилась и не прошла. Заболоцкий не случайно попросил именно Юдина сделать обложку. Перед тем, на Аничковом мосту, рядом с конями Клодта стоял большой, сделанный Юдиным в «кубистических» традициях плакат. Обложка Юдина была сделана в том же принципе: на белом поле стояло короткое, плотное, как бы из камня, монолитное слово «Столбцы». Заболоцкий подарил Юдину книгу с надписью: «Да здравствуют Столбцы № 1!» [Константин Рождественский..., 2006, c. 124$]^{10}$.

По словам Е. В. Заболоцкой, в макете Юдина «...на обложке сверху черным по белому фону было написано СТОЛБЦЫ. Сочные буквы разного размера стояли плотно и воспринимались как единое целое» [Заболоцкий, 1984, с. 386].

\footnotetext{
${ }^{9}$ Ср. замечание И. Н. Карасик: «Подобный прием “невмещающихся слов” использован в шрифтовом листе Юдина, хранящемся в ГТГ (РС-5764)» [Юдин, 2017, с. 428].

${ }^{10}$ Как нам любезно сообщил И. И. Галеев, экземпляр «Столбцов» с дарственной надписью Заболоцкого Юдину был утрачен.
} 
Эти свидетельства противоречат рассказу Синельникова. Запомнившаяся ему обложка «Столбцов» - «яркая, красочная», которая немедленно приковывала взгляд, была исполнена Верой Ермолаевой ${ }^{11}$.

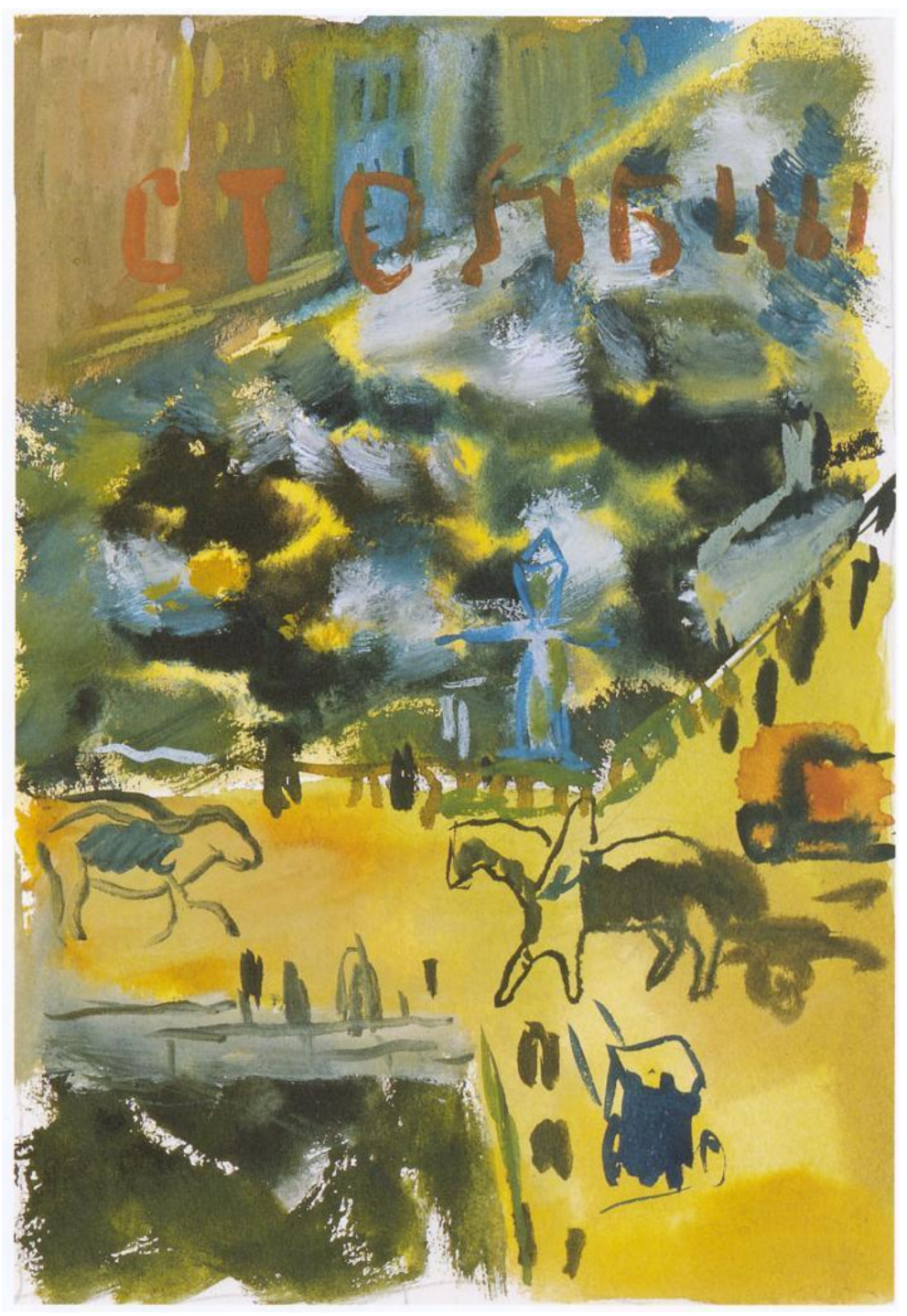

Вера Ермолаева. Эскиз обложки «Столбцов», 1928

Vera Ermolaeva. A draft of "The Pillars" cover (1928)

11 Эскиз обложки (бумага, гуашь. 21,4 × 14,5 см) был передан Т. Б. Казанской в 1969 г. в Русский музей (инв. номер: РС-12356); воспроизведен в каталоге [Вера Михайловна Ермолаева..., 2008, илл. 117]. 
В центре ее экспозиции панорама ленинградской набережной, выдержанная в гамме цветов от бледно-голубого до темно-коричневого. Эскиз выполнен гуашью, которая придала всем оттенкам - от «синеватого серебра» воды в канале до нависающих над ней шоколадных «плоских домов» и «лиловых домиков»особенную глубину. Поэтому ярко-желтый цвет отражений, проглядывающих «сквозь окна в каменной рубахе» огней, контрастирует с песчаным цветом набережной и еле обозначенными черными штрихами перилами моста - то ли через Обводный канал, то ли через Фонтанку, а может быть, и через Невку.

Само название «Столбцы» едва угадывается, зато образы из стихотворений вынесены на обложку прямиком со страниц книги. Здесь есть и «пароходик с музыкой томной по бортам» из «Белой ночи» (или же «праздничный баркас» из «Черкешенки»); «и волны на его дорожке, как бы серебряные ложки» из «Моря»; и «чиновные деревья» из «Ивановых»; и «людские тела», налившиеся, «как груши», из «Лета»; и «фонарь бескровный, как глиста» из «Народного дома»; и «часовой» из одноименного стихотворения, который «стоит, как кукла» на мосту «в шинели конусообразной».

Главные же фигуры обложки - это «вытянутый, как налим», скачущий конь из «Движения»:

А бедный конь руками машет,

то вытянется, как налим,

то снова восемь ног сверкают

в его блестящем животе

[Заболоцкий, 2016, с. 21], -

его противоположность - неспешный битюг из «Обводного канала»:

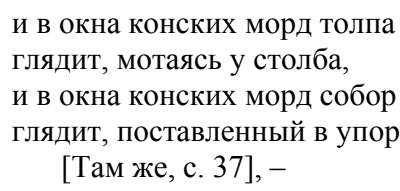

ожившая «телега жизни» из «Пира»: «Она летит - моя телега, / гремя квадратами колес...» [Там же, с. 25], - и незаконченный художницей силуэт, похожий на трамвай, который «шатаясь, чуть идет», - но пусть и неспешно, как ладья Харона, везет своих пассажиров туда, «где можно так любить и грустить»:

И по трамваям рай качается -

тут каждый мальчик улыбается,

а девочка наоборот -

закрыв глаза, открыла рот

и ручку выбросила теплую

на приподнявшийся живот

[Там же, с. 48].

Именно эта обложка, как запомнил Синельников, «вполне отвечала духу книги». В работе Ермолаевой прочитывались «Столбцы» и угадывался их автор, который, если воспользоваться словами Юрия Тынянова, сказанными по другому поводу, своими стихотворениями «не разрушил канонов», а «просто их осмыслил», сделал «домашними все каноны литературы и жизни», «и они оказались не канонами» [Тынянов, 1925, с. 13]. 
Вот почему «дух книги» Заболоцкого оказался «веселым и легким» и отразился в дарственной надписи его другу-сопернику Николаю Олейникову:

Стишочки Ваши прочитавши,

я обрадовался как.

Целу ночку был не спавши -

сию книжечку писал.

Между прочим получивши

ее в подарок от меня,

себе на грудку положите,

сказавши: как люблю тебя.

Сочинил в минуту вдохновения Н. Заболоцкий.

\section{P. S. Равному гению земли}

[Заболоцкий, 2018, с. 134].

Конгениальная «Столбцам» обложка Ермолаевой, тем не менее, осталась единственной ее работой в интерпретации стихотворений «взрослого» Заболоцкого. В дальнейшем их сотрудничество по причине нарастающего идеологического давления на печать продолжалось исключительно в русле детской литературы. В конце 1920-х гг. это направление книжной деятельности превратилось в одну из прерогатив советского издательского процесса ${ }^{12}$. Детское книгоиздательство в Ленинграде находилось под непосредственным присмотром 3. Лилиной, жены Г. Зиновьева и сестры заведующего Госиздатом И. Ионова.

Ермолаева выступила как иллюстратор детских изданий уже в 1928 г. По замечанию ее биографа А. Н. Заинчковской, «группа петроградских писателей и графиков, объединившаяся вокруг журнала "Воробей”, стала ядром будущего Детгиза, идейным вдохновителем и руководителем которого являлся С. Маршак» [Вера Ермолаева..., 2009, с. 55]. Иллюстратор Василий Власов рассказывал, как создавалось художественное крыло детского сектора Госиздата, особенно тепло вспоминая участие Ермолаевой:

Туда шли все, в ком было живое чувство живого искусства. От Малевича пришла В. М. Ермолаева. За ней < ..> Рождественский, Лёва Юдин, Стерлигов. Пришли Якобсон, <...> Зенькович, Певзнер, Тамби. <..> Курдов, Чарушин, Васнецов были аристократами. <..> Другая группа была более разношерстная, объединялась вокруг В. М. Ермолаевой. Тут были и Рождественский с Юдиным, и Зенькович с Великановой, и Кондратьев, и Стерлигов, и даже Юрий Петров. Вера Михайловна любила молодежь, была снисходительной и просто очень доброй [Там же, с. 246].

Литературную часть редакции Маршака составили Натан Венгров, Евгений Шварц, Борис Житков и Николай Олейников. Вслед за ними в редакции появились обэриуты. Даниил Хармс отметил в записной книжке осенью 1927 г.: «Олейников и Житков организовали ассоциацию “Писатели детской литературы”. Мы (Введенский, Заболоцкий и я) приглашаемся» [Дневниковые записи..., 1991, c. 446]. Как вспоминал сын Заболоцкого, это предложение «заинтересовало» его отца, хотя «вначале для детей он писал не стихи, а небольшие прозаические рас-

\footnotetext{
${ }^{12}$ См. об этом до сих пор актуальную, а в те времена чудом вышедшую книгу: [Путилова, 1982]. 
сказы» [Заболоцкий, 2018, с. 110]. Уже ко времени выхода «Столбцов» в его арсенале были рассказ и очерк для детского чтения [Заболоцкий, 1928е; Н. 3., 1928].

Маршак вспоминал, что привлечение обэриутов к работе в Детгизе стало одним из решающих условий его редакционного успеха:

В свое время я привлек эту группу поэтов <... С. Самое большое, чего я мог ждать от них вначале, - это участие в создании тех перевертышей, скороговорок, припевок, которые так нужны в детской поэзии. Но все они оказались способными на гораздо большее, $<\ldots$..> все они оказались при деле, работали в журнале <«Ёж». A. У., И. Л.>, а Заболоцкий даже взял на себя такие большие и трудные задачи, как вольный перевод «Тиля Уленшпигеля» и «Гаргантюа и Пантагрюэля» (цит. по: [Македонов, 1987, с. 164]) ${ }^{13}$.

В письме к Б. Эндеру 12 ноября 1927 г. Ермолаева рассказывала о работе обэриутов в маршаковской редакции:

Я в институте бываю мало и занята совсем другим - делаю сказки и пишу живопись. Сейчас провела вторую книжку с небывалым в моей жизни успехом. Текст написал Введенский, довольно смешной. Эти мальчики теперь работают в Госиздате и увлекаются самой затеей сделать для детей занятно. Хуже всего дела обстоят с Лепорской, Рожд<ественским> и Юдиным. Они впутались в октябрьские диаграммы и, потратив неимоверно много сил, ничего не заработали. Жалко их ужасно, главное - потеря времени. <...>

За этот год я много работаю, и наконец у меня явилось сознание - не шутите я художник. Не шуточное звание [Ермолаева, 1999, с. 173-174].

Обе книжки, которые Ермолаева иллюстрировала и, как она писала Эндеру, «провела» в Детгизе, были «обэриутскими». «Хорошие сапоги» Заболоцкого и «Много зверей» Введенского вышли в первой половине 1928 г. и сформировали общее направление работы редакции Маршака в поэзии для детей. «Вышло совсем неплохо», - ретроспективно замечал сын Заболоцкого [Заболоцкий, 2018 , c. 110], подражая оценочным оговоркам Хармса ${ }^{14}$.

Заболоцкий сочинял свою детскую книжку во время работы над «Столбцами». Неслучайно поэтому почти идентичные строки «Карлуша по улице хмуро идет» и «Карлуша по улице гордо идет» из «Хороших сапог» перекликаются с началом строфы, открывающей центральную часть столбца «Офорт»:

Покойник по улицам гордо идет, его постояльцы ведут под уздцы; он голосом трубным молитву поет и руки ломает наверх

[Заболоцкий, 2016, с. 14].

13 О дальнейшей судьбе редакции Маршака см. не утратившую значения, даже за давностью лет, работу: [Устинов, 1990].

${ }^{14}$ См., например, его записи за июль 1933 г. [Дневниковые записи..., 1991, с. 477], а также замечание Я. Друскина: «Под некоторыми стихотворениями или рассказами Хармса его рукой написано: “хорошо”, “плохо”, “очень плохо”, “отвратительно”. Если автора находит свой рассказ не только “очень плохим", но даже “отвратительным", он уничтожает его. Даниил Иванович сохраняет» [Там же, с. 418]. 
Кроме того, из «Хороших сапог» он позаимствовал ермолаевский рисунок распластанной шкурки для обложки сборника «Арарат» (1928), рукописного предшественника типографских «Столбцов» ${ }^{15}$.

На этом этапе своей литературной биографии Заболоцкий рассматривал детские произведения как еще одну творческую составляющую. Его отношение совпадает с позицией других обэриутов, в первую очередь Хармса, который со свойственной ему последовательностью превратил работу для детской аудитории в одну из вариаций своей творческой деятельности и даже пытался как-то разрабатывать ее жанры, предлагая, например, классификацию в заметке «Веселые, интересные и грустные»:

Веселые годящиеся для всех возрастов. Лишенные почти всякого смысла. Болтливые, с ясной схемой или с обрубленным концом. Получается такой звук, похожий на пузырь из слюней, который выдувает маленький мальчик. Выдул да не до конца, как мыльный. Вернее по схеме вещь получилась почти законченной, но нет конца, потому что нет середины.

Сюжет такой вещи должен отличаться отсутствием [именно] тех сцеплений, которые делают сюжет сюжетом [Дневниковые записи..., 1991, с. 420].

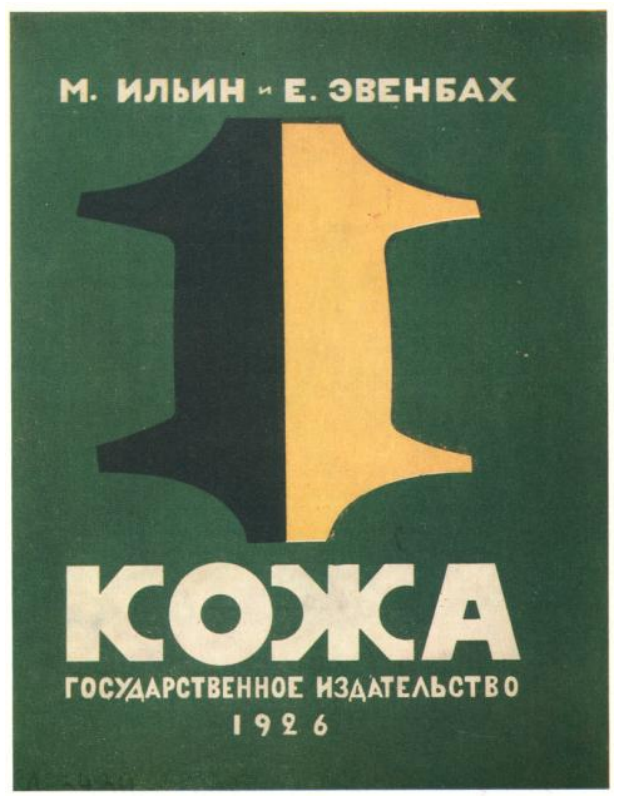

Евгения Эвенбах. Обложка «производственной книжки» М. Ильина (И. Маршака) «Кожа»

Evgeniia Evenbakh. A cover for Ilia Marshak's book "Leather" (1926)

\footnotetext{
${ }^{15}$ РО ИРЛИ (Пушкинский дом). Р. І. Оп. 10. № 144. Л. 1-21. Из «Арарата» в «Столбцы» не вошло только стихотворение «Баллада Жуковского». Ср. замечание, что оформление Ермолаевой «отсылает к обложке детской “производственной” книжки М. Ильина "Кожа”», выполненной Е. Эвенбах [Россомахин, 2103, с. 25]. Репродукцию этой обложки см.: [Матафонов, 1988, с. 65].
} 


\section{Сюжет пространства и сюжет книги}

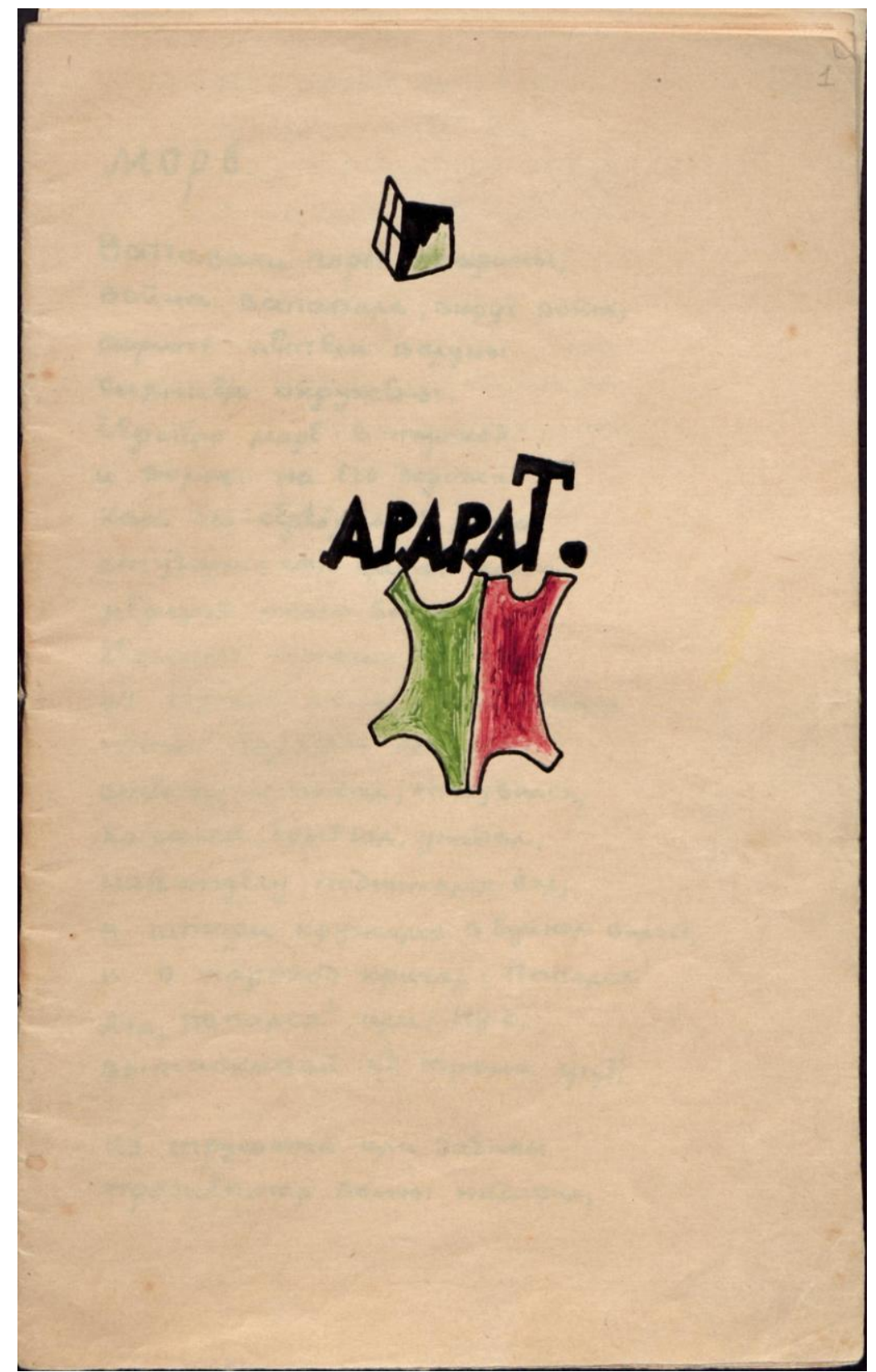

Николай Заболоцкий. Обложка рукописного сборника стихотворений «Арарат» Nikolai Zabolotsky. A cover for his manuscript collection “Ararat” (1928)

Studies in Theory of Literary Plot and Narratology, 2020, no. 1 

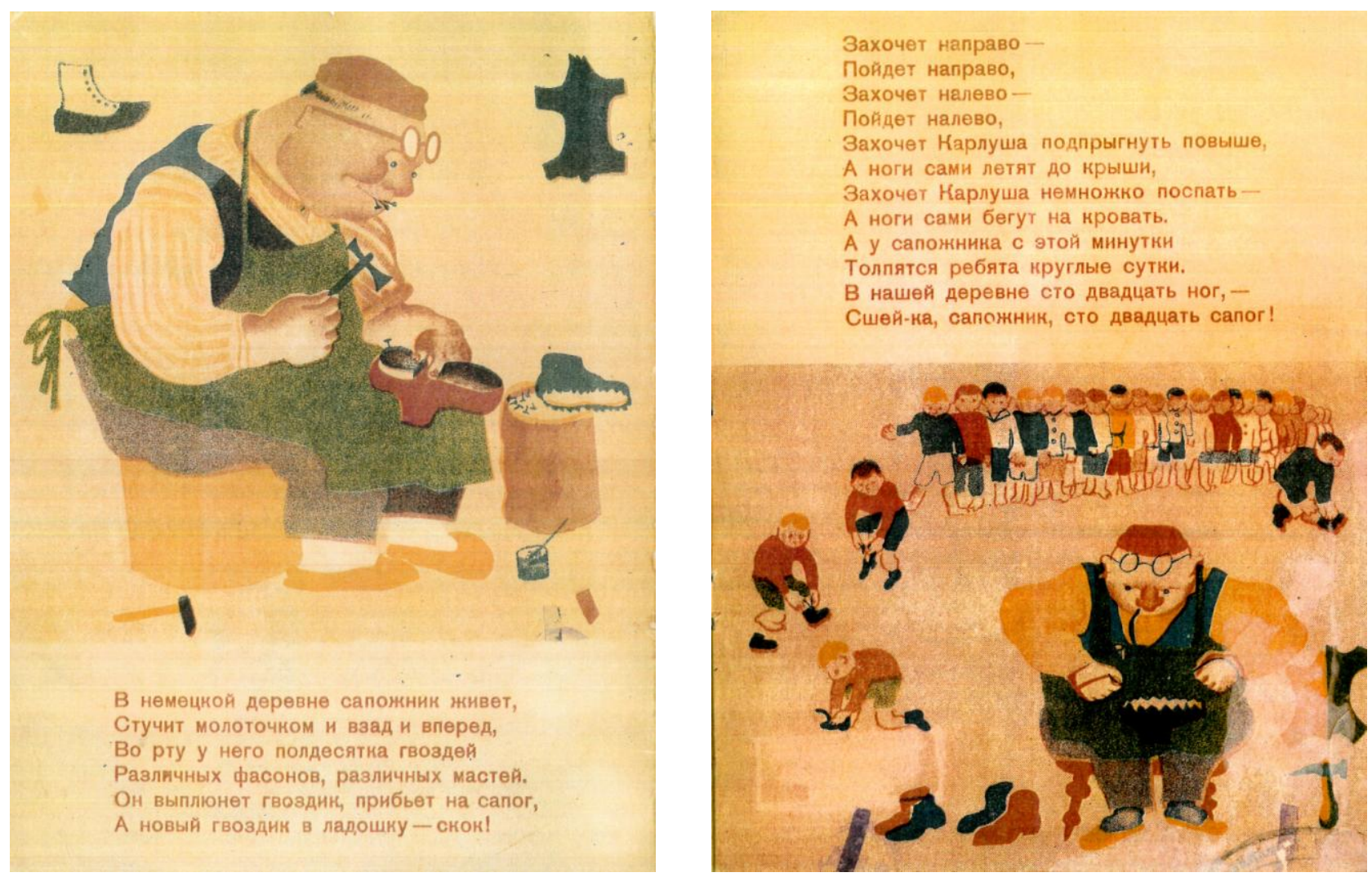

Вера Ермолаева. Первая и последняя страницы книжки Н. Заболоцкого «Хорошие сапоги» Vera Ermolaeva. From Nikolai Zabolotsky’s children's book “Good Boots” (1928) 
Сходного баланса - между серьезной живописной работой и оформлением детских изданий - придерживалась и Ермолаева. Будучи практически на равных ангажирована в Гинхуке и редакции Маршака, она писала Эндеру 11 марта 1928 г. одновременно и о планах выставки в институте, и о выпускаемых Детгизом книжках:

Эта зима кончается, теперь ясно, что она вся прошла в одном - найти пути в собственной живописной работе. Я работала очень много, все углы моей комнаты набиты трупами живописными, гуашными и карандашными. Очень решительно настаиваю на том, чтобы связать себя сроком выступления на выставке. Если все эти трупы не дадут еще через год хорошего ростка, то и делать нечего в искусстве. Эти ростки и тут, и там видны, но собрать сильно $<\mathrm{e}>$ одно ощущение мне за зиму не удалось. Посмотрим, что будет летом. Юдин работал над многими, очень еще слабыми ощущениями, но теперь вернулся к своим женщинам и прорабатывает их заново на новом материале. $<\ldots>$

Помните, что Вам уже готова комната на выставке, что на Ваш лес я рассчитываю, что все мы мысленно прикидываем свой вид между другими холстами, размеры, количество и прочее.

С группой Малевича мы вместе не выставляем, так как они отмежёвываются на супрематизме и не хотят ослаблять остроту и чистоту выступления. <...>

Мои успехи только в детской книжке. Если проведу сейчас четыре книжки, то

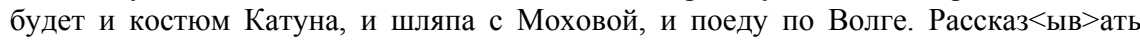
можно еще бесконечно, хоть и тихо идет жизнь и бедно, но внутри всё кипит и полно. $<\ldots>$

Книжки Вам свои пришлю, они имеют успех, а отпечатаны отвратительно [Ермолаева, 1999, с. 175-177].

Позднее Ермолаева проиллюстрировала журнальные публикации стихотворений Заболоцкого [Миллер, 1930; 1931]. Тогда же оформлением его детских рассказов стал заниматься и Юдин, который присоединился к маршаковской редакции. В самом конце 1928 - начале 1929 г. он работает над несохранившейся книгой Заболоцкого «Индейцы» ${ }^{16}$ и, как и в случае с афишей для вечера «Три левых часа», фиксирует весь процесс работы в дневнике.

«Делаю вторую сказку “Индейцы”, - записывал он 18 декабря 1928 г. - Поиски цвета. Спектр и отношение к нему» [Юдин, 2017, с. 209], - возможно, решив выполнить эти иллюстрации, в отличие от обложки «Столбцов», в цвете. 2223 декабря Юдин отвлекается на «стихийное веселье у В. М. $<$ Ермолаевой.> Маски шум смех. Кипенье жизни, молодости!!», радуется «1-ой внутригрупповой выставке» и жалуется: «“Индейцы” делаются пока очень туго. Пожалуй, сяду с ними. Тогда плохо. Работа пока стоит» [Там же, с. 210]. Однако 14 января 1929 г. отмечает свой триумф: «Сегодня сдал “Индейцев”. Блестящая победа (в самом факте сдачи больше, чем в вещи). Если пройдут - будет здорово» [Там же, с. 211].

Вопреки его надеждам, книга в свет не вышла, но летом 1929 г. в журнале «Ёж» появился «Пропавший рассказ», который был проиллюстрирован Юдиным [Без подписи, 1929б, с. 20-24] ${ }^{17}$. Несомненно, этот большой игровой рассказ име-

\footnotetext{
${ }^{16}$ См. репродукцию: [Кузнецова, 1970, с. 117].

${ }^{17}$ На оборотной стороне обложки, закрывающей предшествующий, шестой выпуск журнала, в качестве анонса были воспроизведены другие юдинские «рисунки к рассказу,
} 
ет отношение к «Индейцам» и, хотя в журнале он не подписан, с большой вероятностью автором его был Заболоцкий.

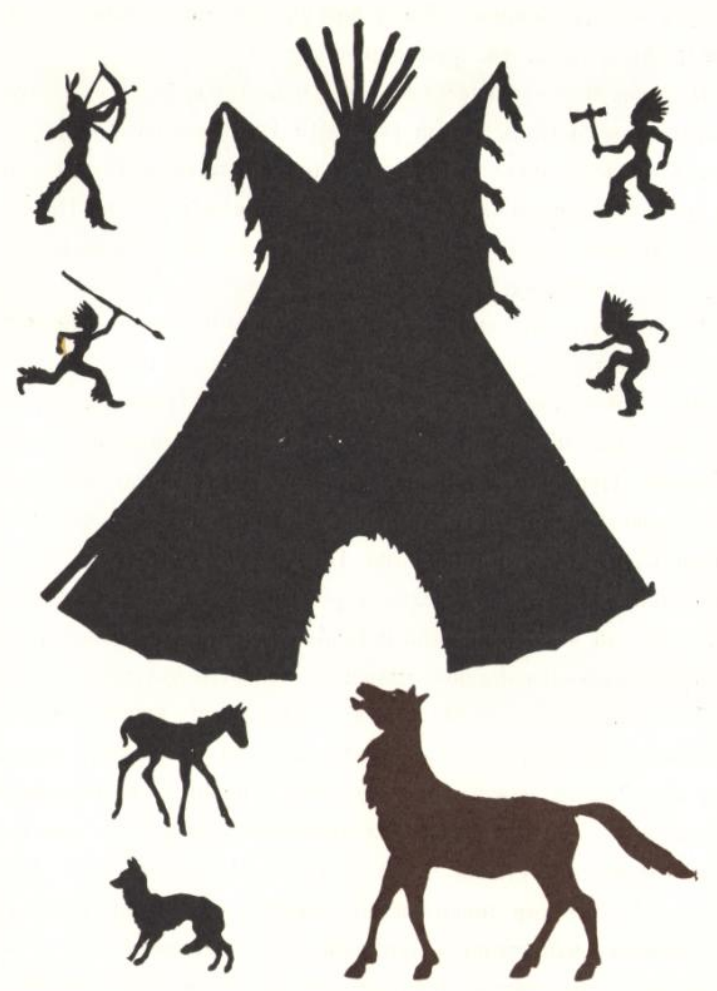

Лев Юдин. Иллюстрация к рассказу Николая Заболоцкого «Индейцы», 1929

Lev Yudin. An illustration for Nikolai Zabolotsky’s short story “The Indians” (1929)

который будет помещен в седьмом номере “Ежа"». Силуэты, стилистически связанные с иллюстрациями к «Индейцам», печатались в «Еже» либо без подписей (1928: № 11, с. 22, 29; № 12, с. 37; 1929: № 1, с. 37 ; № 5, с. 30), либо с различными пояснениями: «Что за звери?» (1928, № 9, с. 35), «Ответ на вопрос “Куда убежали звери?”» (1928, № 10, с. 33-34; силуэты использовались в этом выпуске для декоративного оформления страниц, исключая с. 5, 9-10, 12-13, 24, 26-27 и 32); «Что везут эти звери?» (1928, № 11, оборот второй обложки); «Кого допрашивал Макар Свирепый?» (1929, № 3, с. 10); «Таинственные следы» (1929, № 4, с. 27; с сопровождающей подписью: «Наш художник не рисует, а вырезает зверей из черной бумаги. Он это делает очень быстро - раз-раз ножницами - и готово. Быстрее фотоаппарата»); «Здесь нарисована кошка и ее родственники» $(1929$, № 8, с. 10). В № 8 (на обороте второй обложки) юдинские звери, пальмы, индейцы и вигвамы появились в последний раз - с использованием цвета и элементов техники коллажа. В композиционном центре были вклеены фотография лощади и лицо «всадника» Николая Олейникова. «Это последний рисунок Макара Свирепого, - гласила подпись. - Называется он “Я в пути”. Зверей и деревья Макар рисовал по памяти, а себя и лошадь в зеркало». 
Закончив оформление этой сказки, Юдин принялся за оформление книги «Цирк», названной так по одноименному стихотворению, которое было напечатано в феврале 1929 г. в журнале «Звезда» и включалось в позднейшие редакции «Столбцов». Неизвестно, какие именно стихи вошли в эту книгу, но можно предположить, что, полагаясь на свой предыдущий опыт с «Белым снегом», художник задумал исполнить «Цирк», как livre d'artiste. Поэтому в проекте обложки Заболоцкий указан только как автор стихов, а «остальное всё - Льва Юдина».

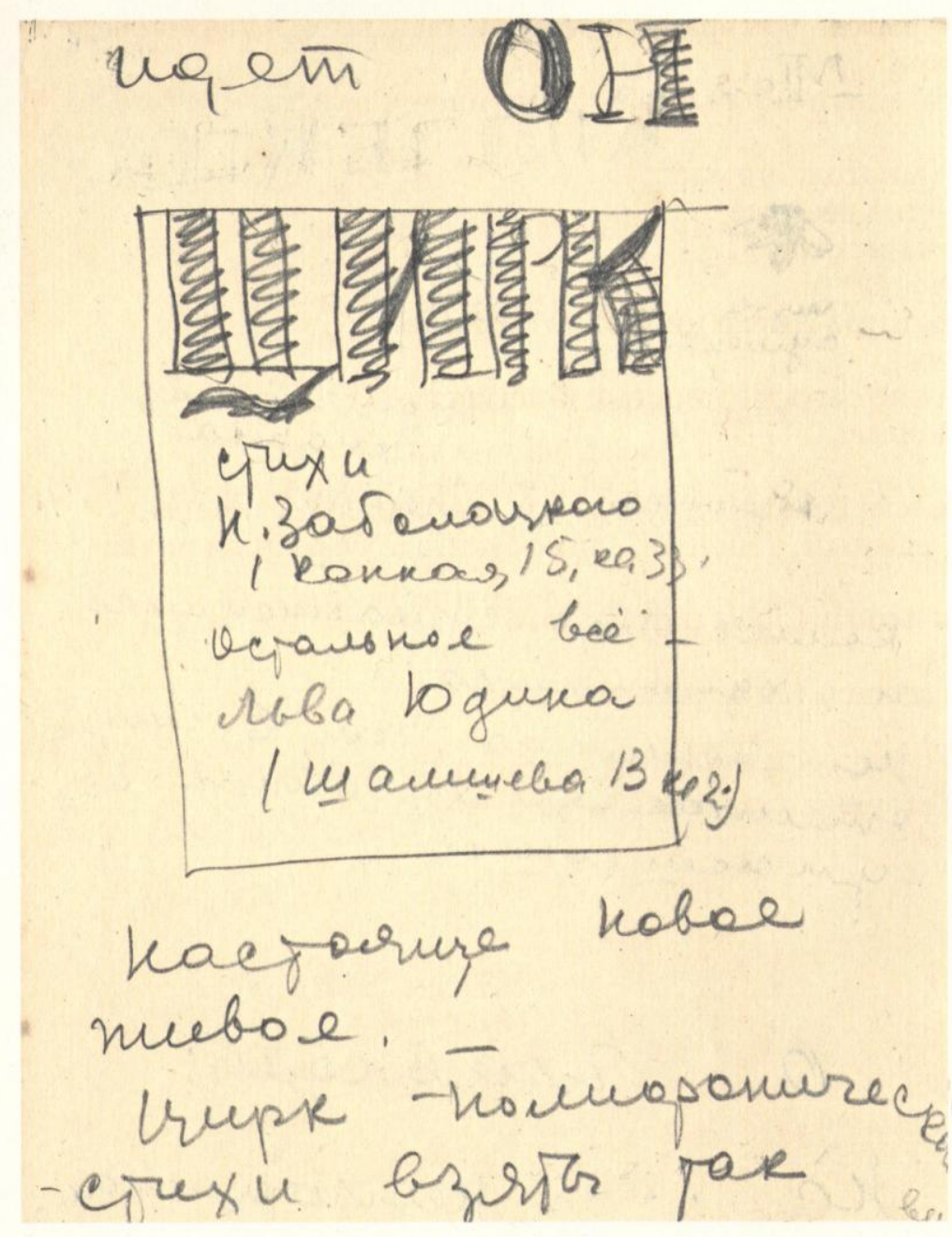

Лев Юдин. Фрагмент страницы дневника с записями от 21 января 1929 г.

Lev Yudin. An page from his diary (1929)

ISSN 2410-7883

Сюжетология и сюжетография. 2020. №

Studies in Theory of Literary Plot and Narratology, 2020, no. 
Экспозиции книги «Цирк» посвящены записи последней декады января:

О ГЛАВНОМ:

НА... неэмоциональную, холодную живопись. Зреет новый подлинный период. $<\ldots>$

\section{Ц И Р К}

стихи

Н. Заболоцкого

(Конная, 15, кв. 33)

Остальное всё-

Льва Юдина

(Шамшева 13 кв. 2)

Цирк - полифоническая вещь - стихи взяты так же точно, как в джаз-банде тема. Целый мир вариаций.

Новые взаимоотношения поэта и художника.

Шум, хрип, визг, веселье, перебои, антракты. Накурено, душно, высоко летит шарманка

визжит поэзия

от восторга

идет настоящее искусство.

Я - арлекин. Я рыжий у ковра, я передразниваю всех, я должен включить в себя весь цирк.

Мимоходом шлепнул силача по крутому плечу, подставил кому-то ножку, сам упал.

Эх, Вагинов много понимает: -

У нас есть девочки веселые

Они танцуют чарльстон...

$<\ldots>$

Последняя страница $<$ «>Цирка <»> цитата из Вагинова.

$<\ldots>$

В «Цирке» должно быть мастерство! И легкость!

Истинно цирковые.

Полифония вовсю! Разные сорта бумаги, материалы, размеры, ощущения, один, единый, точеный, шлифованный безумный ритм!

Быть бы мне композитором или поэтом!

Или танцором...

Но можно это сделать и в нашем искусстве.

А в живописи... У-у-хх! Попробовать рвануть по-нашему, по-Шамшевски (Петрушка хвастлив... и скромен).

Даешь эмоцию!

Хуже нет равнодушной живописи.

$<$ «> Цирк $<»>-$ альбомного формата.

У нас есть девочки хорошие $<.>$

Они танцуют чарльстон.

Неужели я не сделаю.

Петрушка легкомыслен и непостоянен. 
Сюжет пространства и сюжет книги

В то же время глубок серьезен верен себе.

Кручёных навязал искусству свою фамилию.

Надо навязать искусству Шамшеву улицу. <..>

Нет джаз-банда - будет шарманка [Юдин, 2017, с. 212-215].

Юдин намеревался сделать такие иллюстрации для «Цирка», в которых он мог бы интерпретировать образы «Столбцов» подобно тому, как это удалось Ермолаевой. В другом месте дневника он записал по поводу программного стихотворения сборника Заболоцкого: «“Белая ночь” - замечательная вещь. Передана действительность до физической навязчивости» [Там же, с. 243]. В «Цирке» она должна была передаваться под звуки джаз-банда и чарльстона ${ }^{18}$. Такую «физическую навязчивость» он трактовал как одно из проявлений «реального искусства» в обэриутской поэзии и стремился передать ее в своих иллюстрациях. «Зачем ездить в Париж, - записывал он в другом месте, - искусство здесь, под боком». Если же каких-то образов не доставало, их можно было с легкостью подменить: «Нет джаз-банда - будет шарманка» [Там же, с. 215].

С таким подходом связано и настойчивое использование Юдиным конкретных деталей - своего и Заболоцкого точных адресов и многократно «Шамшевой улицы». Как полагает И. Н. Карасик, «Юдин не случайно делает адреса значимыми элементами обложки. Шамшева для него не просто место жительства, но некий символ веры» [Там же, с. 435]. Для обэриутов это - также характерный литературный прием. Своему стихотворению «Землю, говорят, изобрели конюхи» (1925) Хармс предпослал посвящение «Тем, кто живет на Конюшенной» - т. е. своей музе Эстер Русаковой [Jaccard, Ustinov, 1991, S. 190-193]. А у Заболоцкого было стихотворение «Конная улица», которое не сохранилось, но упоминается в его переписке с редакцией журнала «Чудак» ${ }^{19}$.

Юдин работает над «Цирком» на протяжении всей весны 1929 г. и ведет записи в дневнике: «Сделаны кое-какие заметки к “Цирку”. Ничего пока не разобрать» (4 февраля); «Сделаны эскизы к “Цирку”. Много обещают» (8 марта); «Цирк. Цирк. Цирк. Маленькие вещи, такие заражающие и живые!..» (11 марта) [Юдин, 2017 , с. 221, 222, 225]. Однако итог оказывается неутешительным: «Так и не вышел “Цирк” Заболоцкого», - записывает он в конце июля 1929 г., потерпев второе после «Индейцев» фиаско с их совместным проектом.

В первой половине 1930-х гг. у поэта складывается сотрудничество с художником Павлом Кондратьевым (1902-1985), вышедшим из коллектива «Мастера Аналитического Искусства», где он работал под руководством П. Филонова, и дружившим с Хармсом [Дневниковые записи..., 1991, с. 554-555]. Последний наделил его фамилией нескольких своих персонажей, например, басни «Однажды господин Кондратьев / попал в американский шкаф для платьев» (1933) [Хармс, 1980, с. 50]. Кондратьев тогда же оформил два стихотворения Заболоцкого в жур-

\footnotetext{
${ }^{18}$ Приводимые Юдиным строки «У нас есть девочки веселые / Они танцуют чарльстон...», которые он собирался поместить на обложку, среди дошедших до нас сочинений К. Вагинова не встречаются.

${ }^{19}$ РГАЛИ. Ф. 1433. ОП. 2. Ед. хр. 51.
} 
нале «Чиж» [Н. 3., 1933; Заболоцкий, 1933а] ${ }^{20}$. Иллюстрируя «Сказку о кривом человечке», он изобразил самого поэта как рассказчика, а его сына как маленького слушателя $^{21}$. Под своим именем Никита Заболоцкий появляется не только в детских стихах отца («Что такое а ля брасс?», «Как мыши с котом воевали»), но и во «взрослом» стихотворении «Утренняя песня» $(1933)^{22}$, которое читается как посвящение Заболоцкого всем своим художникам.

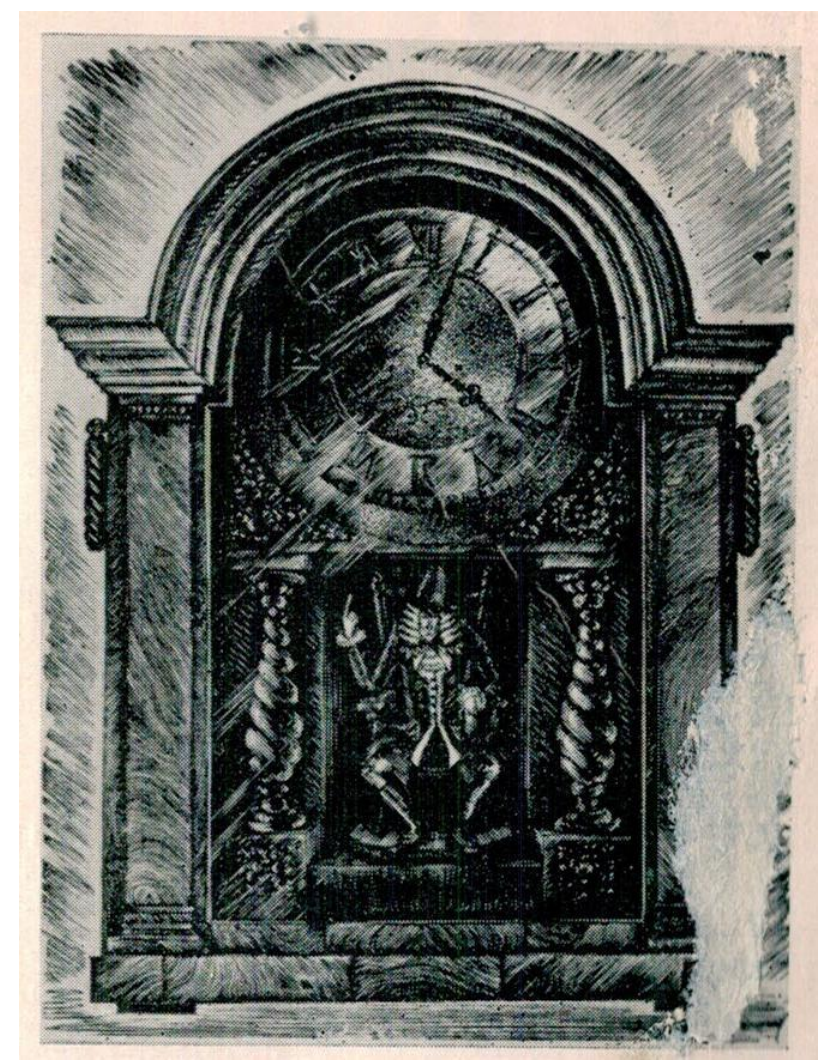

Наталья Фандерфлит. Неизданная иллюстрация к «Сказке о кривом человечке» Николая Заболоцкого, 1933 <?> Natalia Fanderflit. An illustration for Nikolai Zabolotskii’s poem (1933)

\footnotetext{
${ }^{20}$ Еще один вариант иллюстраций к «Сказке о кривом человечке» выполнила Наталья Фандерфлит (1901-1996); см.: [Павел Александрович Шиллинговский..., 1981, с. 71]. Стихотворение Заболоцкого ошибочно названо здесь «сказкой “Часы”». На соседней странице упоминается иллюстрация художницы к стихотворению Заболоцкого «Картонный город», которое было напечатано с рисунком без подписи художника [Заболоцкий, 1933б, с. 1].

${ }^{21}$ См. об этом: [Павел Михайлович Кондратьев..., 2014, с. 49-50].

22 Первоначально это стихотворение было названо «Семейство художника». Несмотря на проставленную под ним дату «1932 год», Е. В. Заболоцкая считала, что оно было закончено только в 1933-м [Заболоцкий, 2018, с. 158].
} 


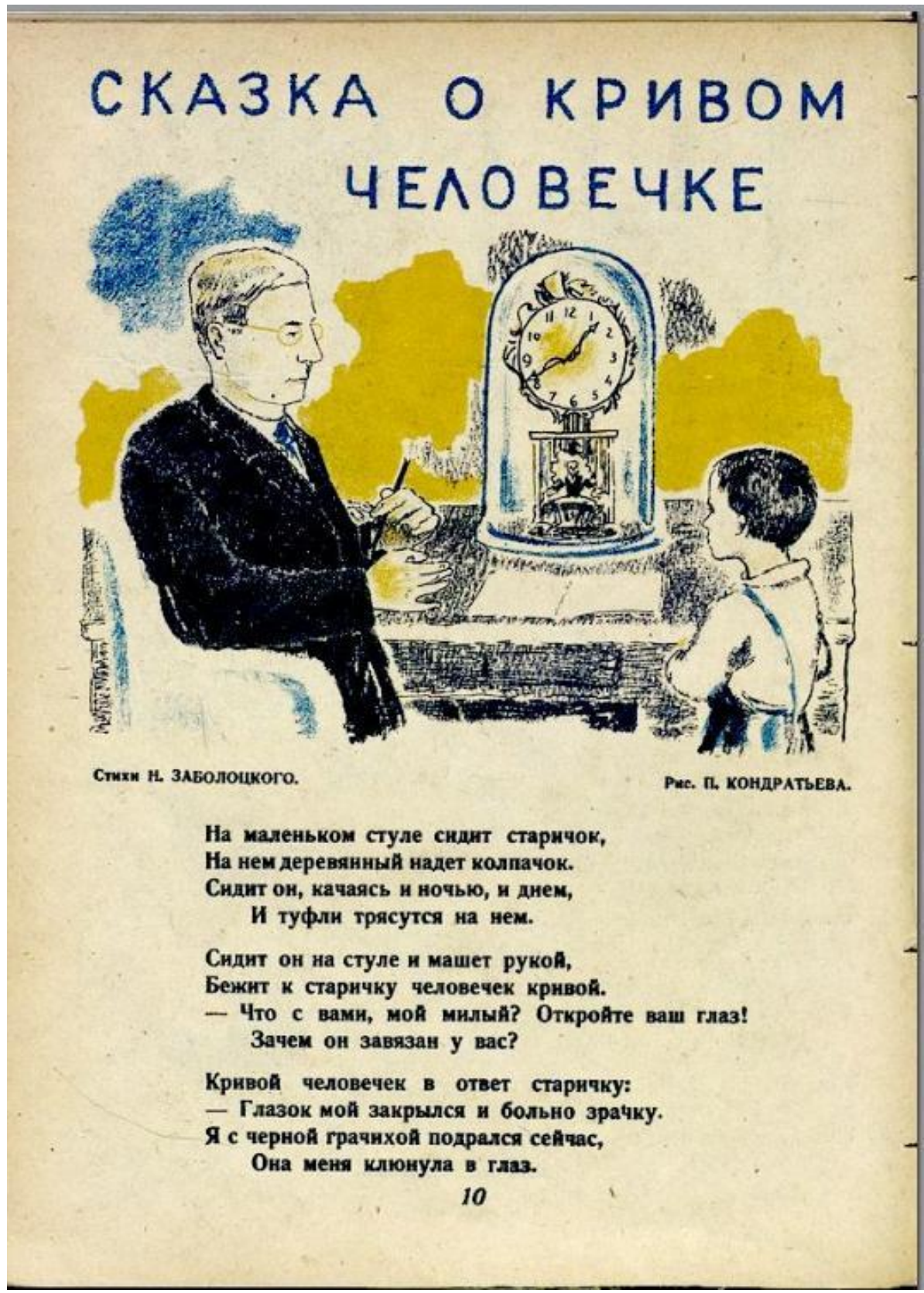

Павел Кондратьев. Иллюстрация

к «Сказке о кривом человечке» Николая Заболоцкого (Чиж. 1933. № 8. С. 10)

Pavel Konsratiev. An illustration from children's magazine "Siskin" (1933) 


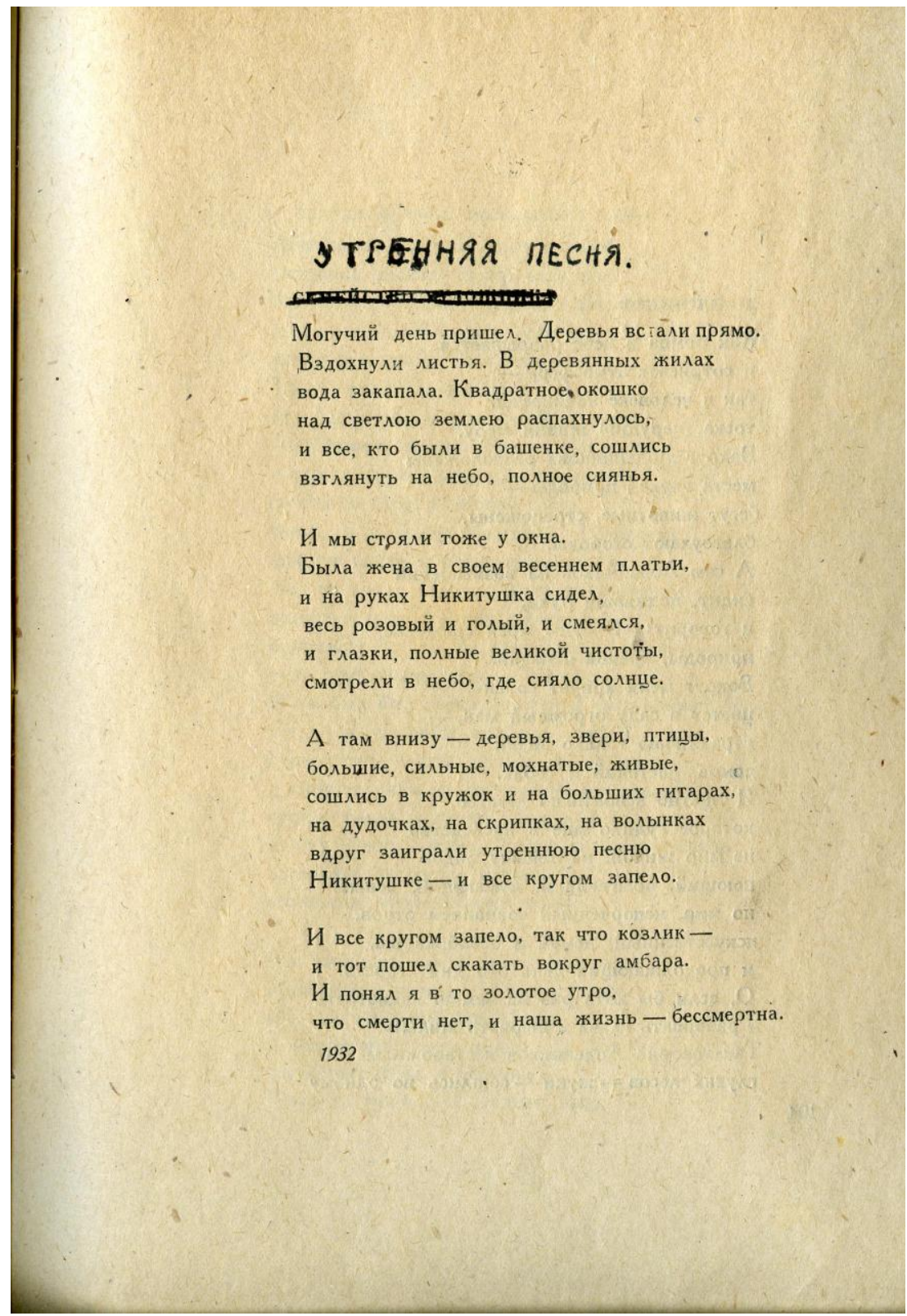

Из корректуры неизданной книги: Заболоикий Н. Стихотворения 1926-1932 / Вступ. ст. И. Виноградова [Л.: Издательство писателей в Ленинграде, 1933]. С. 103

Nikolai Zabolotsky. A page from the proofs of his unpublished book "Poems 1926-1932" 


\section{Список литературы}

[Без подписи] Литературная хроника // Жизнь искусства. 1929а. № 4 (1234). C. 22.

[Без подписи] Пропавший рассказ: Редакционное сообщение / Рис. Л. Юдина // Еж. 1929б. № 7. С. 20-24.

Вера Михайловна Ермолаева. 1893-1937 / Авт.-сост. Л. Вострецова, Т. Горячева, А. Заинчковская. СПб.: Palace Editions-Graficart, 2008. 143 с.

Вера Ермолаева. 1893-1937 / Текст и коммент. А. Заинчковской; вступ. ст. И. Галеева. М.: Скорпион; Галеев Галерея, 2009. 287 с.

Вокруг Хармса / Публ., предисл. и примеч. Вл. Эрля // Транспонанс. 1984. № 21. С. $<99-129>$.

Воспоминания о Заболоцком / Сост. Е. Заболоцкая, А. Македонов, Н. Заболоцкий. 2-е изд., доп. М.: Сов. писатель, 1984. 462 с.

Двинятина Т. М. Книги в Коллекции П. Н. Лукницкого // Ежегодник Рукописного Отдела Пушкинского Дома на 2002 г. / Отв. ред. Т. Царькова. СПб.: Дмитрий Буланин, 2006. С. 573-586.

Дневниковые записи Даниила Хармса / Публ. А. Устинова, А. Кобринского. $<$ Вступ. ст. и коммент. А. Устинова $>/ /$ Минувшее. Исторический альманах. 11. Paris, 1991. С. 417-583.

Ермолаева В. Шесть писем к Б. В. Эндеру (1927-29) / Публ. З. Масетти-Эндер // Experiment / Эксперимент. 1999. Vol. 5. Р. 173-179.

Заболоикий Н. Красная Бавария // Костер. Л.: Ленингр. Союз поэтов, 1927а. C. 27-30.

Заболоикий Н. Футбол // Звезда. 1927б. № 12. С. 100-101.

Заболочкий Н. Игра в снежки // Ленинградская правда. 1928а. № 127 (3933), 2 июня. Литературное приложение. № 11. С. 4.

Заболоикий Н. Обед // Ленинградская правда. 1928б. № 93 (3899), 21 апр. Литературное приложение. № 8. С. 6.

Заболоцкий Н. Поприщин // Ленинградская правда. 1928в. № 24 (3840), 28 янв. Литературное приложение. 1928. № 2. С. 8.

Заболоцкий Н. Поход // Ленинградская правда. 1928г. № 259 (3776), 13 нояб. C. 3 .

Заболоцкий Н. Руки // Ленинградская правда. 1928д. № 60 (3870), 10 марта. Литературное приложение. № 5. С. 3.

Заболоикий Н. Сережка колбасник / Рис. П. Староносова // Дружные ребята. 1928e. № 6. C. 4-10.

Заболочкий Н. Сказка о кривом человечке / Рис. П. Кондратьева // Чиж. 1933а. № 8. C. 10-13.

Заболоцкий Н. Картонный город // Чиж. 1933б. № 11. С. 1.

Заболоиякий Н. Собр. соч.: В 3 т. / Сост. Е. Заболоцкая, Н. Заболоцкий. М.: Худож. лит., 1984. Т. 3: Переводы. Из грузинской классической поэзии. Из поэзии Советской Грузии; Письма. 1921-1958. 416 с.

Заболоцкий Н. Столбцы / Изд. подг. Н. Заболоцкий, И. Лощилов. М.: Наука, 2016. 531 с. (Сер. «Литературные памятники»)

Заболоикий Н. Николай Заболоцкий: История жизни / Под ред. И. Лощилова. СПб.: Вита Нова, 2018. 512 с. 
Книги и рукописи в собрании М. С. Лесмана: Аннотированный каталог. Публикации / Сост. М. Лесман. М.: Книга, 1989. 462 с.

Константин Рождественский. К 100-летию со дня рождения / Авт.-сост. И. Вакар, Т. Михиенко. М.: ГТГ, 2006. 576 с.

Кузнещова Э. Искусство силуэта. Л.: Художник РСФСР, 1970. $131 \mathrm{c.}$

Кулаков В. Поэзия как факт: Статьи о стихах. М.: НЛО, 1999. 400 с.

Македонов А. Николай Заболоцкий: Жизнь. Творчество. Метаморфозы. Л.: Сов. писатель, 1987. 365 с.

Малевич К. С. Собр. соч.: В 5 т. / Под ред. А. Шатских. М.: Гилея, 2003. Т. 4: Трактаты и лекции первой половины 1920-х годов, с приложением переписки К. С. Малевича и Эль Лисицкого (1922-1925). 358 с.

Матафонов В. Евгения Константиновна Эвенбах. Л.: Художник РСФСР, 1988. $181 \mathrm{c}$.

Миллер Я. <Заболоикий Н.> На реке / Рис. В. Ермолаевой // Чиж. 1930. № 6. C. 4-5.

Миллер Я. <Заболоикий Н.> Первый сбор / Рис. В. Ермолаевой // Маленькие ударники. Н. Новгород: ОГИЗ, 1931. Вып. 1. С. 5-6.

H. 3. <Заболоикий H.> Пионеры шведские и пионеры советские / Рис. В. Гринберга // Еж. 1928. № 8. С. 22-23.

H. 3. <Заболоикий Н.> Песня туриста / Рис. П. Кондратьева // Еж. 1933. № 6. C. $1-2$.

Павел Александрович Шиллинговский и его ученики: Каталог выставки / Сост. Е. Гришина, Д. Сафаралиева. Л.: Искусство, 1981.72 с.

Павел Михайлович Кондратьев. Живопись, книжная и станковая графика / Авт.-сост. И. Галеев. М.: Галеев Галерея, 2014. 288 с.

Путилова Е. Очерки по истории критики советской детской литературы, 1917-1941. М.: Дет. лит., 1982. 175 с.

Россомахин А. «С виду будто бы ничего особенного, а приглядишься...»: Потерянный ключ к книге Заболоцкого // «Вечно светит лишь сердце поэта...» / Сост. Т. Игошева, И. Лощилов. М.: Азбуковник, 2013. С. 19-34.

Тынянов Ю. Льву Лунцу. Письмо-некролог // Ленинград. 1925. 20 июня. № 22 (61). C. 13.

Устинов А. Дело детского сектора Госиздата 1932 г. (Предварительная справка) // Михаил Кузмин и русская культура XX века / Сост. и ред. Г. Морева. Л.: Музей Анны Ахматовой в Фонтанном доме, 1990. С. 125-136.

Хармс Д. Собрание произведений / Под ред. М. Мейлаха, Вл. Эрля. Bremen: K-Presse Verlag, 1980. Кн. 3: Стихотворения 1931-1933. 238 с.

Юдин Л. «Сказать - свое...»: Дневники. Документы. Письма. Свидетельства современников / Под ред. И. Карасик. М.: RA, 2017. 903 с.

Jaccard J.-Ph., Ustinov A. Заумник Даниил Хармс: Начало пути // Wiener Slawistischer Almanach (München). 1991. Bd. 27. S. 159-228.

\section{Архивы}

Рукописный отдел Института русской литературы (Пушкинского Дома) РАН (РО ИРЛИ РАН, СПб.).

Российский государственный архив литературы и искусства (РГАЛИ, М.). 


\section{References}

[Anonymous] Literaturnaya khronika. Zhizn' Iskusstva [Life of Art], 1929, no. 4 (1234), p. 22. (in Russ.)

[Anonymous] Propavshiy rasskaz: Redaktsionnoe soobshchenie, ris. L. Yudina. Ezh [Heghehog], 1929, no. 7, p. 20-24. (in Russ.)

Dnevnikovye zapisi Daniila Kharmsa. Publ. by A. Ustinov, A. Kobrinsky. <Intr. and comment. by A. Ustinov>. In: Minuvshee. Istoricheskiy al'manakh [Past], vol. 11. Paris, 1991, p. 417-583. (in Russ.)

Dvinyatina T. Knigi v Kollektsii P. N. Luknitskogo. In: Ezhegodnik Rukopisnogo Otdela Pushkinskogo Doma na 2002 g. [Pushkinsky Dom. Dept. of Manuscripts. Yearly for 2002]. Ed. by T. Tsarkova. St. Petersburg, Dmitriy Bulanin Publ., 2006, p. 573-586. (in Russ.)

Ermolaeva V. Shest' pisem k B. V. Enderu (1927-29). Publ. by Z. Masetti-Ender. Experiment / Eksperiment (A Journal of Russian Culture), 1999, vol. 5, p. 173-179. (in Russ.)

Kharms D. Collected Works. Ed. by M. Meylakh, Vl. Erl. Bremen, K-Presse Verlag, 1980, book 3: Stikhotvoreniya 1931-1933, 238 p. (in Russ.)

Jaccard J.-Ph., Ustinov A. Zaumnik Daniil Kharms: Nachalo puti. Wiener Slawistischer Almanach (München), 1991, Bd. 27, S. 159-228. (in Russ.)

Knigi i rukopisi v sobranii M. S. Lesmana: Annotirovanny katalog. Publikatsii [Books and Manuscripts in Moisei Lesman's Collection]. Comp. by M. Lesman. Moscow, Kniga Publ., 1989, 462 p. (in Russ.)

Konstantin Rozhdestvensky. K 100-letiyu so dnya rozhdeniya [Konstantin Rozhdestvensky. A Centenary]. Comp. by I. Vakar, T. Mikhienko. Moscow, GTG Publ., 2006, 576 p. (in Russ.)

Kulakov V. Poeziya kak fakt: Stat'i o stikhakh [Poetry as a Fact]. Moscow, NLO Publ., 1999, 400 p. (in Russ.)

Kuznetsova E. Iskusstvo silueta [Art of the Silhouette]. Leningrad, Khudozhnik RSFSR Publ., 1970, 131 p. (in Russ.)

Makedonov A. Nikolai Zabolotsky: Zhizn'. Tvorchestvo. Metamorfozy [<Nikolai Zabolotsky: Life. Art. Metamorphoses]. Leningrad, Sovetskiy pisatel' Publ., 1987. 365 p. (in Russ.)

Malevich K. S. Collected Works. In 5 vols. Ed. by A. Schatskikh. Moscow, Gileya, 2003, vol. 4: Traktaty i lektsii pervoy poloviny 1920-kh godov, s prilozheniem perepiski K. S. Malevicha i El Lisickogo (1922-1925), 358 p. (in Russ.)

Matafonov V. Evgeniya Konstantinovna Evenbakh. Leningrad, Khudozhnik RSFSR, 1988, 181 p. (in Russ.)

Miller Ya. <Zabolotsky N.> Na reke, ris. V. Ermolaevoy. Chizh [Siskin], 1930, no. 6, p. 4-5. (in Russ.)

Miller Ya. < Zabolotsky N.> Pervy sbor, ris. V. Ermolaevoy. In: Malen'kie udarniki [Little Achievers]. Nizhny Novgorod, Ogiz Publ., 1931, iss. 1, p. 5-6. (in Russ.)

N. Z. < Zabolotsky N.> Pesnya turista, ris. P. Kondratieva. Ezh [Hedgehog], 1933, no. 6, p. 1-2. (in Russ.)

N. Z. <Zabolotsky N.> Pionery shvedskie i pionery sovetskie, ris. V. Grinberga. Ezh [Hedgehog], 1928, no. 8, p. 22-23. (in Russ.) 
Pavel Aleksandrovich Schillingovsky i ego ucheniki. Katalog vystavki [Pavel Shillingovsky and his Students]. Comp. by E. Grishina, D. Safaralieva; intr. by. E. V. Grishina. Leningrad, Iskusstvo Publ., 1981, 72 p. (in Russ.)

Pavel Mikhailovich Kondratiev. Comp. by I. Galeev. Moscow, Galeev Galereya, 2014, 288 p. (in Russ.)

Putilova E. Ocherki po istorii kritiki sovetskoy detskoy literatury, 1917-1941 [Essays on the History of the Criticism of Soviet Children's Literature]. Moscow, Detskaya literatura Publ., 1982, 175 p. (in Russ.)

Rossomahin A. "S vidu budto by nichego osobennogo, a priglyadish'sya...": Poteryanny klyuch k knige Zabolotskogo. In: "Vechno svetit lish' serdtse poeta..." [“Only Poet's Heart Shines Forever”]. Comp. by T. Igosheva, I. Loshchilov. Moscow, Azbukovnik, 2013, p. 19-34. (in Russ.)

Tynyanov Yu. L'vu Luntsu. Pis'mo-nekrolog [To Lev Lunts. An Obituary Letter]. Leningrad, 1925, 20 June, no. 22 (61), p. 13. (in Russ.)

Ustinov A. Delo detskogo sektora Gosizdata 1932 g. (Predvaritel'naya spravka). In: Mikhail Kuzmin i russkaya kul'tura XX veka [Mikhail Kuzmin and Russian Culture of the $20^{\text {th }}$ Century]. Comp. and ed. by G. Moreva. Leningrad, Muzey Anny Akhmatovoy v Fontannom dome, 1990, p. 125-136. (in Russ.)

Vera Ermolaeva. 1893-1937. Comment. by A. Zainchkovskaya; intr. by I. Galeev. Moscow, Skorpion; Galeev Galereya, 2009, 287 p. (in Russ.)

Vera Mikhaylovna Ermolaeva. 1893-1937. Comp. by L. Vostretsova, T. Goryacheva, A. Zainchkovskaya. St. Petersburg, Palace Editions-Graficart, 2008, 143 p. (in Russ.)

Vokrug Kharmsa. Publ., intr. and comment. by V. Erl. Transponans, 1984, no. 21, p. $<99-129>$. (in Russ.)

Vospominaniya o Zabolotskom [Memories of Zabolotsky]. Comp. by E. Zabolotskaya, A. Makedonov, N. Zabolotsky. $2^{\text {nd }}$ ed. Moscow, Sovetsky pisatel' Publ., 1984, 462 p. (in Russ.)

Yudin L. "Skazat' - svoe...": Dnevniki. Dokumenty. Pis'ma. Svidetel'stva sovremennikov ["To Say Your own..." Diaries. Documents. Letters. Memoirs]. Ed. by I. Karasik. Moscow, RA, 2017, 903 p. (in Russ.)

Zabolotsky N. Krasnaya Bavariya. In: Koster [Bonfire]. Leningrad, Leningradsky Soyuz poetov, 1927, p. 27-30. (in Russ.)

Zabolotsky N. Futbol. Zvezda [Star], 1927, no. 12, p. 100-101. (in Russ.)

Zabolotsky N. Igra v snezhki. Leningradskaya pravda [Leningrad Truth], 1928, no. 127 (3933), 2 June, Literaturnoe prilozhenie, no. 11, p. 4. (in Russ.)

Zabolotsky N. Obed. Leningradskaya pravda [Leningrad Truth], 1928, no. 93 (3899), 21 Apr., Literaturnoe prilozhenie, no. 8, p. 6. (in Russ.)

Zabolotsky N. Pokhod. Leningradskaya pravda [Leningrad Truth], 1928, no. 259 (3776), 13Nov., p. 3. (in Russ.)

Zabolotsky N. Poprishchin. Leningradskaya pravda [Leningrad Truth], 1928, no. 24 (3840), 28 Jan., Literaturnoe prilozhenie, 1928, no. 2, p. 8. (in Russ.)

Zabolotsky N. Ruki. Leningradskaya pravda [Leningrad Truth], 1928, no. 60 (3870), 10 March, Literaturnoe prilozhenie, no. 5, p. 3. (in Russ.)

Zabolotsky N. Serezhka kolbasnik, ris. P. Staronosova. Druzhnye rebyata [Friends], 1928, no. 6, p. 4-10. (in Russ.)

Zabolotsky N. Kartonny gorod. Chizh [Siskin], 1933, no. 11, p. 1. (in Russ.) 
Zabolotsky N. Nikolai Zabolotsky: Istoriya zhizni [Nikolai Zabolotsky: A Life]. Ed. by I. Loshchilov. St. Petersburg, Vita Nova Publ., 2018, 512 p. (in Russ.)

Zabolotsky N. Skazka o krivom chelovechke, ris. P. Kondratieva. Chizh [Siskin] (Leningrad), 1933, no. 8, p. 10-13. (in Russ.)

Zabolotsky N. Collected Works. In 3 vols. Comp. by E. Zabolotskaya, N. Zabolotsky. Moscow, Khudozhestvennaya literatura Publ., 1984, vol. 3: Perevody. Iz gruzinskoy klassicheskoy poezii. Iz poezii Sovetskoy Gruzii; Pis'ma. 1921-1958, 416 p. (in Russ.)

Zabolotsky N. Stolbtsy [Pillars]. Prep. by N. Zabolotsky, I. Loshchilov. Moscow, Nauka, 2016. 531 p. (Literaturnye pamyatniki) (in Russ.)

\section{Archives}

Rukopisny otdel Instituta russkoy literatury (Pushkinskogo Doma) RAN (RO IRLI RAN, SPb.) [Pushkinskii Dom. Department of Manuscripts].

Rossiysky gosudarstvenny arkhiv literatury i iskusstva (RGALI, M.) [Russian State Archives of Art and Literature].

\section{Сведения об авторах}

Устинов Андрей Борисович - доктор филологических наук, директор книгоиздательства «Аквилон» (Сан-Франциско, США)

abooks@gmail.com

ORCID 0000-0002-8468-4854

Лощилов Игорь Евгеньевич - кандидат филологических наук, ведущий научный сотрудник сектора литературоведения Института филологии СО РАН (Новосибирск, Россия), доцент кафедры русской и зарубежной литературы, теории литературы и методики обучения литературе Новосибирского государственного педагогического университета (Новосибирск, Россия)

loshch@yandex.ru

ORCID 0000-0003-3642-2590

\section{Information about the Authors}

Andrei B. Ustinov - PhD, Dr. Hab.; philologist; Director of the "Aquilon" Books \& Publishing (San Francisco, USA)

abooks@gmail.com

ORCID 0000-0002-8468-4854

Igor E. Loshchilov - Candidate of Philology, $\mathrm{PhD}$, researcher of Literary Studies Section of the Institute of Philology of Siberian Branch of Russian Academy of Sciences (Novosibirsk, Russian Federation); Associate Professor of the Department of Russian Literature and Literary Theory of Novosibirsk State Pedagogical University (Novosibirsk, Russian Federation)

loshch@yandex.ru

ORCID 0000-0003-3642-2590 